\title{
DOM fluorescence, a tracer for biogeochemical processes in a coastal upwelling system (NW Iberian Peninsula)
}

\author{
M. Nieto-Cid*, X. A. Álvarez-Salgado, J. Gago, F. F. Pérez \\ CSIC, Instituto de Investigacións Mariñas, Eduardo Cabello 6, 36208 Vigo, Spain
}

\begin{abstract}
Fluorescence of dissolved organic matter (FDOM) was determined for the first time during a complete seasonal cycle in a coastal upwelling system (Ría de Vigo, NW Spain). Specific excitation/emission wavelengths for the refractory humic substances and the labile aromatic amino acids were detected and quantified. The distribution of the fluorescence of marine humic substances $\left(\mathrm{FDOM}_{\mathrm{M}}\right)$ correlated significantly with nutrient salts $(\mathrm{r}=0.62, \mathrm{p}<0.001)$ and dissolved oxygen $(\mathrm{r}<$ $-0.71, p<0.001)$, after removal of the effect of water masses mixing. It suggests that humic substances are a by-product of organic matter mineralisation processes in shelf bottom waters. It was estimated that about $10 \%$ of the organic carbon degraded in the water column was transformed into humic substances, which were produced in the ría at a rate of about $0.1 \mathrm{ppb}$ eq (parts per billion equivalents) quinine sulphate $\mathrm{d}^{-1}$. The distribution of the fluorescence of dissolved aromatic amino acids $\left(\mathrm{FDOM}_{\mathrm{T}}\right)$ correlated significantly with the distribution of particulate proteins $(r>0.57, \mathrm{p}<0.001) . \mathrm{FDOM}_{\mathrm{T}} \mathrm{can}$ be used to trace sites of net accumulation of labile DOM in (1) the photic layer (at a rate of about $0.5 \mathrm{ppb}$ eq tryptophan $\mathrm{d}^{-1}$ ), where labile DOM is produced from phytoplankton exudation and/or lysis and (2) the bottom nepheloid layer (at a rate of about $0.2 \mathrm{ppb}$ eq tryptophan $\mathrm{d}^{-1}$ ), due to an in situ enhancement of the microbial activity and/or a release from sediment pore waters.
\end{abstract}

KEY WORDS: Dissolved organic matter $\cdot$ Fluorescence $\cdot$ Humic substances $\cdot$ Amino acids $\cdot$ Seasonal cycle $\cdot$ Coastal upwelling $\cdot$ NW Iberian Peninsula

\section{INTRODUCTION}

Seawater dissolved organic matter (DOM) is one of the largest and least understood reservoirs of reduced carbon of the earth's surface (Hedges 1992, 2002, Hansell 2002). Most efforts to characterise DOM have been focused on the C/N/P elemental composition, while molecular constituents have not been studied in detail. Currently, $<30 \%$ of the molecular composition of DOM is known (Yamashita \& Tanoue 2003). While information on the elemental composition of DOM is essential to understand the origin and fate of natural organic matter, knowledge of its molecular composition is crucial to provide insights into the dynamics of the DOM pool (Ogawa \& Tanoue 2003). The main problem researchers face in the molecular characteri- sation of DOM stems from the low concentrations of the individual constituents in seawater, a difficulty that has been partly overcome through the improvement of ultrafiltration methods (Amon \& Benner 1996). Ultrafiltration is a powerful tool in combination with nuclear magnetic resonance techniques (Benner et al. 1992, Aluwihare et al. 1997, McCarthy et al. 1997, Clark et al. 1998, Hedges et al. 2002). Nevertheless, these methods require very large samples $\left(10^{2}\right.$ to $\left.10^{3} 1\right)$, and the physical and chemical properties of the concentrate differ from the original sample. Simple, quick and sensitive methods are still necessary to facilitate DOM characterisation within the requirements of hydrographic sampling.

Fluorescence spectroscopy has been used in recent decades to characterise DOM. Results from these 
studies have provided valuable information about the chemical nature (fluorescence functional groups) and distribution (fluorescence intensity) of DOM. In addition to simplicity, sensitivity and quickness, the small sample volume requirement is another attraction of this technique. It was applied first to the study of humic substances (Cabaniss \& Shuman 1987, Hayase et al. 1988, Chen \& Bada 1992). Coble et al. (1990) were pioneers in the use of excitation/emission matrices (EEMs) to study DOM fluorescence. EEMs helped to allocate the 2 main fluorophores of natural DOM: (1) the humiclike fluorophores, which have been studied since the 1960s, and (2) the protein-like fluorophores, which are due to aromatic amino acids (Mopper \& Schultz 1993, Determann et al. 1996, 1998, Coble et al. 1998).

Humic substances are a heterogeneous mixture of complex high-molecular-weight biopolymers, with structures still not fully understood. They constitute a significant fraction of DOM: between 30 and $50 \%$ of dissolved organic carbon (DOC) in natural waters (Thurman 1985). Obernosterer \& Herndl (2000) observed that humic compounds comprised $15 \pm 7 \%$ of DOC in the Adriatic Sea and $43 \pm 7 \%$ of DOC in coastal waters of the North Sea. Although humic substances are considered a refractory DOM pool, they are microbially produced and photochemically degraded. Therefore, the fluorescence of humic compounds is a suitable parameter to study these biogeochemical processes.

The fluorescence of aromatic amino acids (tyrosine, tryptophan and phenylalanine) is a useful indicator of the dynamics of dissolved free amino acids (DFAA) in general (Yamashita \& Tanoue 2003). These simple molecules are among the most labile biogenic compounds. Therefore, protein-like fluorescence can be used to study the dynamics of labile DOM.

DOM fluorescence has mainly been used in studies of estuarine mixing (Jaffé et al. 2004), photodegradation (Obernosterer \& Herndl 2000, Del Vecchio \& Blough 2002) and DFAA distributions (Yamashita \& Tanoue 2003). Comparatively few examinations comparing DOM fluorescence with DOC or nutrient distributions have been performed (Chen \& Bada 1992, Hayase \& Shinozuka 1995, Chen et al. 2002), and all were focused on humic-like fluorescence.

The importance of DOM for carbon and nutrient cycles is enhanced in coastal waters, where exudation by aquatic organisms and degradation of marine and terrestrial plant matter produce large amounts of DOM (Nagata 2000, Carlson 2002). Coastal waters support 18 to $33 \%$ of the global net primary production and 27 to $50 \%$ of the global export production (Walsh 1991, Chavez \& Toggweiler 1995, Wollast 1998). DOM production is especially intense in coastal upwelling areas in response to nutrient fertilisation from the adjacent ocean (Doval et al. 1997, Hansell \& Carlson 1998, Álvarez-Salgado et al. 2001a). Organic matter produced in upwelling areas can experience extreme oxidising and reducing conditions (Gagosian et al. 1978).

The NW Iberian Peninsula is characterised by (1) an upwelling season, with successive upwelling pulses separated by short intervals of calm, which favour nutrient recycling and enhance primary production (Álvarez-Salgado et al. 1999), and (2) a second season dominated by downwelling episodes, distinguished by low primary production rates. During an upwelling event, northerly winds cause the uplift of Eastern North Atlantic Central Water (ENACW) over the shelf, which enters the rías and enhances the characteristic 2-layer circulation pattern (Rosón et al. 1997). Other conspicuous phenomena in this region are the incursion of the Iberian Poleward Current (IPC) along the slope during winter, carrying subtropical waters to these latitudes (Haynes \& Barton 1990, ÁlvarezSalgado et al. 2003).

Previous studies of this coastal upwelling region focused on the elemental composition of DOM (Doval et al. 1997, Álvarez-Salgado et al. 1999, 2001b). A recent study in NW Iberian shelf waters was devoted to the molecular characterisation of DOM. In a previous article, Nieto-Cid et al. (2004) studied the role of carbohydrates in the DOM cycle of this system. The aim of the present work was to use DOM fluorescence to further characterise DOM during a seasonal cycle. The value of humic-like fluorophores, as indicators of the humification associated with mineralisation processes, and of the protein-like fluorophores, as indicators of DOM lability, are the key points in this study.

\section{MATERIALS AND METHODS}

Survey area. Two domains were sampled during this study: the Rías Baixas and the adjacent shelf (Fig. 1). A 2-layered residual circulation pattern characterises the rías, with an ingoing bottom current and an outgoing surface current during upwelling events, and a reversal of the flow during downwelling conditions. These large $\left(>2.5 \mathrm{~km}^{3}\right)$, V-shaped embayments respond predominantly to shelf winds (Gilcoto et al. 2001, Souto et al. 2003), and, to a lesser extent, to continental runoff. For the case of the Ría de Vigo, the main tributary is the river Oitabén-Verdugo, with an average flow of $18 \mathrm{~m}^{3} \mathrm{~s}^{-1}$ during the study period (Fig. 1).

The circulation of shelf waters off the Rías Baixas is more complex; it is composed of a wind-driven longshore current and across-shore exchanges with the adjacent ocean and rías. During the upwelling season, the rías and the shelf are coupled: shelf surface waters are imported from the rías and the bottom waters of the 
Fig. 1. Map of the Ría de Vigo and the adjacent shelf (NW Iberian Peninsula). The positions of the 3 hydrographic stations and the SeaWatch buoy off Cape Silleiro are shown. In the inset, the main tributary to the Ría de Vigo, the river Oitabén-Verdugo. The Eiras station, in the upper course of the river, is also indicated

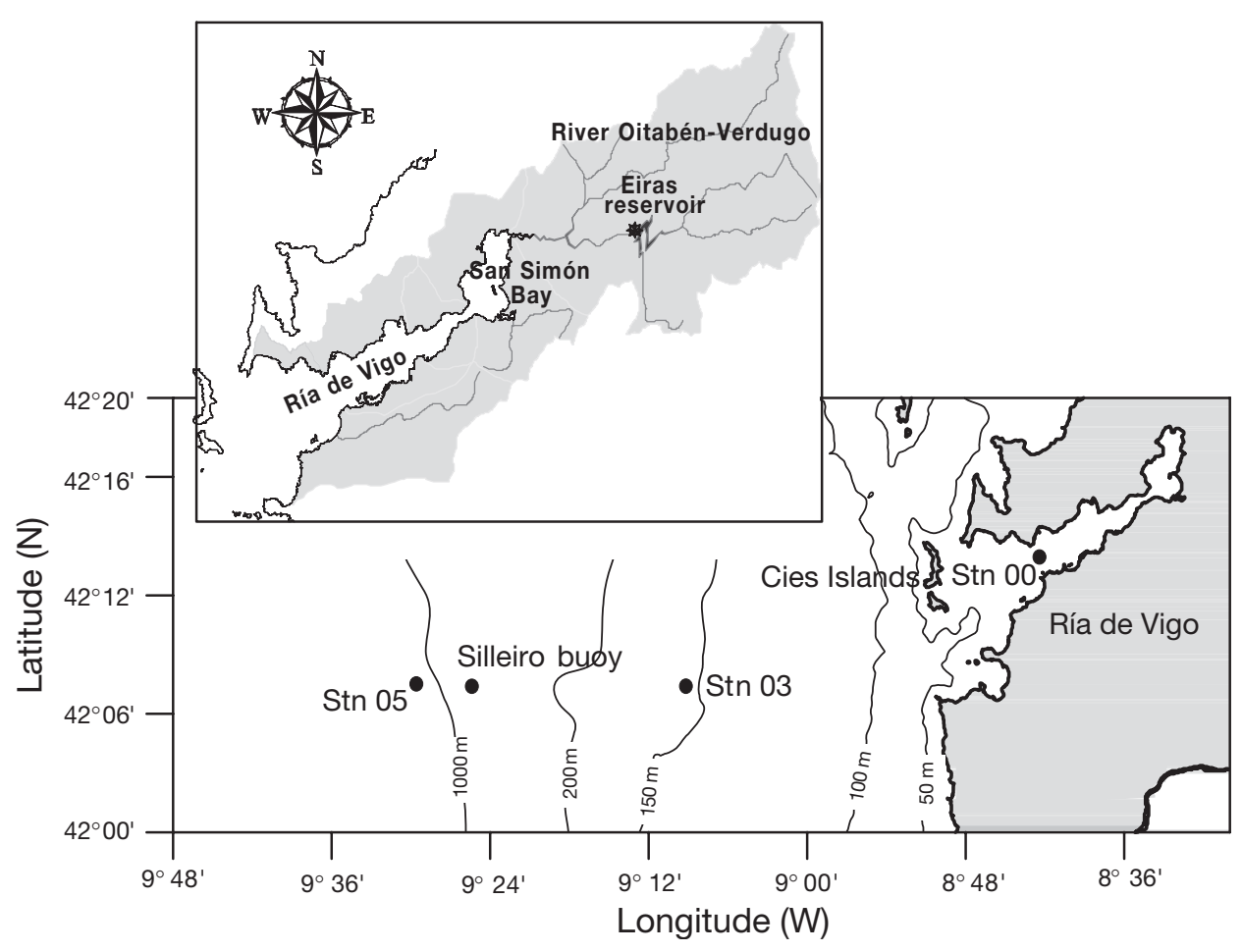

rías enter from the shelf. On the contrary, during the downwelling season, a convergence front develops between the shelf and the rías. The position of this front in the long-shore direction depends on the relative strength of coastal winds and continental runoff (Álvarez-Salgado et al. 2000).

Sampling strategy. Two stations were sampled weekly aboard RV 'Mytilus' from May 2001 to April 2002: a mid-shelf station (Stn $03 ; 42^{\circ} 07.8^{\prime} \mathrm{N}, 9^{\circ} 10.2^{\prime} \mathrm{W}$; $150 \mathrm{~m}$ deep) and a mid-ría station (Stn $00 ; 42^{\circ} 13.8^{\prime} \mathrm{N}$, $8^{\circ} 51.0^{\prime} \mathrm{W} ; 40 \mathrm{~m}$ depth in low water). Full-depth continuous conductivity-temperature-depth (CTD) profiles were recorded at each sampling site with an SBE 9/11 CTD device incorporated into a rosette sampler equipped with twelve 101 Niskin bottles. Conductivity measurements were converted into practical salinity scale values (UNESCO 1985). Seawater samples were collected from 5, 25, 40, 60, 75, 100 and $150 \mathrm{~m}$ at Stn 03, and 5, 15 and $40 \mathrm{~m}$ at Stn 00. Samples for oxygen $\left(\mathrm{O}_{2}\right)$, nutrient salts, dissolved organic carbon and nitrogen (DOC/DON) and particulate organic carbon and nitrogen (POC/PON) analyses were collected during every survey (weekly periodicity), whereas samples for DOM fluorescence (FDOM) were taken during every other survey (2 wk periodicity). A glossary of abbreviations is provided in Table 1.

In addition, 1 station in the upper course of the river Oitabén-Verdugo was sampled regularly during the seasonal cycle (Eiras reservoir, Fig. 1). Surface samples
Table 1. Glossary of relevant terms

$\begin{array}{ll}\text { AOU } & \text { Apparent oxygen utilisation } \\ \text { BNL } & \text { Bottom nepheloid layer } \\ \mathrm{C}_{\text {Lip }} & \text { Carbon content of particulate lipids } \\ \mathrm{C}_{\text {Prot }} & \text { Carbon content of particulate proteins } \\ \Delta \text { FDOM, } & \text { Fluorescent DOM excess at the surface or at the } \\ \delta \text { FDOM } & \text { bottom layer, and net accumulation of fluores- } \\ & \text { cent DOM in the ría and on the outer shelf } \\ \text { DFAA } & \text { Dissolved free amino acids } \\ \text { DOC } & \text { Dissolved organic carbon } \\ \text { DOM } & \text { Dissolved organic matter } \\ \text { DON } & \text { Dissolved organic nitrogen } \\ \text { EEM } & \text { Excitation/emission matrix } \\ \text { ENACW } & \text { Eastern North Atlantic Central Water } \\ \text { FDOM } & \text { DOM fluorescence at peak } \mathrm{M}\left(\lambda_{\mathrm{ex}} / \lambda_{\mathrm{em}} 320 / 410 \mathrm{~nm}\right) \\ \text { FDOM } & \text { DOM fluorescence at peak } \mathrm{T}\left(\lambda_{\mathrm{ex}} / \lambda_{\mathrm{em}} 280 / 350 \mathrm{~nm}\right) \\ \mathrm{IPC} & \text { Iberian Poleward Current } \\ \mathrm{O}_{2 \mathrm{C}} & \text { Corrected } \\ & \text { dissolved oxygen } \\ \text { p-CHO } & \text { Particulate carbohydrates } \\ \text { POC } & \text { Particulate organic carbon } \\ \text { PON } & \text { Particulate organic nitrogen } \\ \text { POP } & \text { Particulate organic phosphorous } \\ \text { QSU } & \text { Quinine sulphate units (correspond to ppb eq QS) } \\ Q_{\mathrm{R}} & \text { Continental runoff } \\ -Q_{\mathrm{X}} & \text { Daily Ekman transport } \\ \text { TDN } & \text { Total dissolved nitrogen } \\ & \end{array}$


for DOC/DON, POC/PON, nutrients and DOM fluorescence were taken with a 1.71 Niskin bottle. They were processed in the same way as the seawater samples.

Chemical analysis. Aliquots for dissolved and particulate organic matter analyses were collected in $500 \mathrm{ml}$ acid-cleaned glass flasks and $5 \mathrm{l}$ acid-cleaned PVC containers, respectively. Suspended organic matter was collected under low vacuum on precombusted $\left(450^{\circ} \mathrm{C}, 4 \mathrm{~h}\right), 25 \mathrm{~mm}$ diameter Whatman $\mathrm{GF} / \mathrm{F}$ filters for POC/PON (0.5 to $1.5 \mathrm{l}$ of seawater filtered). All filters were dried overnight and frozen $\left(-20^{\circ} \mathrm{C}\right)$ before analysis.

Measurements of POC and PON were carried out with a Perkin Elmer 2400 CHN analyser. Standards of acetanilide were run daily. The precision of the method was $\pm 0.3 \mu \mathrm{M} \mathrm{C}$ and $\pm 0.1 \mu \mathrm{M} \mathrm{N}$.

Dissolved oxygen was determined by Winkler potentiometric end-point titration using a Titrino 720 analyser (Metrohm), with a precision of $\pm 0.5 \mu \mathrm{mol}$ $\mathrm{kg}^{-1}$. The apparent oxygen utilisation $\left(\mathrm{AOU}=\mathrm{O}_{2}\right.$ sat $\mathrm{O}_{2}$ ) was calculated using the algorithm proposed by Benson \& Krause (UNESCO 1986) for oxygen saturation $\left(\mathrm{O}_{2}\right.$ sat $)$.

Samples for nutrient analyses were collected in $50 \mathrm{ml}$ polyethylene bottles; they were kept cold $\left(4^{\circ} \mathrm{C}\right)$ for a few hours until analysis in the laboratory using standard segmented flow analysis (SFA) procedures. The precision was $\pm 0.02 \mu \mathrm{M}$ for nitrite, $\pm 0.1 \mu \mathrm{M}$ for nitrate, $\pm 0.05 \mu \mathrm{M}$ for ammonium, $\pm 0.02 \mu \mathrm{M}$ for phosphate and $\pm 0.05 \mu \mathrm{M}$ for silicate.

DOM samples were filtered through precombusted $\left(450^{\circ} \mathrm{C}, 4 \mathrm{~h}\right), 47 \mathrm{~mm}$ diameter Whatman GF/F filters in an acid-cleaned glass filtration system, under low $\mathrm{N}_{2}$ flow pressure; 2 aliquots were collected, for DOC/DON and DOM fluorescence.

Samples for the analysis of DOC/DON were collected in $10 \mathrm{ml}$ precombusted $\left(450^{\circ} \mathrm{C}, 12 \mathrm{~h}\right)$ glass ampoules. After acidification with $\mathrm{H}_{3} \mathrm{PO}_{4}$ to $\mathrm{pH}<2$, the ampoules were heat-sealed and stored in the dark at $4^{\circ} \mathrm{C}$ until analysis. DOC and DON were measured simultaneously with a nitrogen-specific Antek 7020 nitric oxide chemiluminescence detector, coupled in series with the carbon-specific infrared gas analyser of a Shimadzu TOC-5000 organic carbon analyser (Álvarez-Salgado \& Miller 1998). The system was standardised daily with a mixture of potassium hydrogen phthalate and glycine. The concentrations of DOC and total dissolved nitrogen (TDN) were determined by subtracting the average peak area from the instrument blank area and dividing by the slope of the standard curve. The precision of measurements was $\pm 0.7 \mu \mathrm{M}$ for carbon and $\pm 0.2 \mu \mathrm{M}$ for nitrogen. Their respective accuracies were tested daily with the DOM reference materials provided by Prof. D. Hansell (Miami University). We obtained average concentrations of $45.7 \pm$
1.6 $\mu \mathrm{M} \mathrm{C}$ and $21.3 \pm 0.7 \mu \mathrm{M} \mathrm{N}(\mathrm{n}=26)$ for the deep ocean reference (Sargasso Sea deep water, $2600 \mathrm{~m}$ ) minus blank reference materials. The nominal DOC value provided by the reference laboratory is $44.0 \pm$ $1.5 \mu \mathrm{M} \mathrm{C}$; a consensus TDN value has not been set yet, but a mean value of $22.1 \pm 0.8 \mu \mathrm{M} \mathrm{N}$ has been provided by Sharp et al. (2004) after the Lewes intercalibration exercise. DON was obtained by subtracting $\mathrm{N}_{\mathrm{T}}$ (total inorganic nitrogen $=$ ammonium + nitrite + nitrate) from TDN.

DOM fluorescence methodology. FDOM was measured with a Perkin Elmer LS 55 luminescence spectrometer, equipped with a xenon discharge lamp, equivalent to $20 \mathrm{~kW}$ for $8 \mu$ s duration. The instrument has 2 monochromators that ranged between 200 and $800 \mathrm{~nm}$ for excitation wavelengths and between 200 and $900 \mathrm{~nm}$ for emission wavelengths. The detector was a red-sensitive R928 photomultiplier, and a photodiode worked as reference detector. Slit widths were $10.0 \mathrm{~nm}$ for the excitation and emission wavelengths, and scan speed was set at $250 \mathrm{~nm} \mathrm{~min}{ }^{-1}$. Measurements were performed at a constant room temperature of $20^{\circ} \mathrm{C}$ in a $1 \mathrm{~cm}$ quartz fluorescence cell. Milli-Q water was used as a reference for fluorescence analysis.

EEMs were performed to track the main fluorophores. These matrices were generated by combining 21 synchronous excitation/emission fluorescence spectra of the sample, obtained at a constant offset between the excitation and emission wavelengths of $10 \mathrm{~nm}$. The spectra were collected starting from the highest excitation wavelength, to minimise the exposure of the sample to low-wavelength radiation and thereby minimise photodegradation. Milli-Q water EEMs were performed every day, in order to correct the Raman scatter band.

The following fluorescence peaks have been found in the EEMs of riverine and seawater samples (Fig. 2a,b): A, due to general humic substances (average $\lambda_{\text {ex }} / \lambda_{\text {em }}=250 / 435 \mathrm{~nm}$ ); , due to terrestrial-origin humic substances (average $\lambda_{\mathrm{ex}} / \lambda_{\mathrm{em}}=340 / 440 \mathrm{~nm}$ ); $M$, due to marine-origin humic substances (average $\left.\lambda_{\mathrm{ex}} / \lambda_{\mathrm{em}}=320 / 410 \mathrm{~nm}\right) ;$ and $\mathrm{T}$, due to aromatic amino acids, specifically tryptophan (average $\lambda_{\text {ex }} / \lambda_{\text {em }}=280 /$ $350 \mathrm{~nm}$ ). These peaks are consistent with those found by Coble et al. (1990), Mopper \& Schultz (1993) and Coble (1996) for the $\lambda_{\text {ex }} / \lambda_{\text {em }}$ range of these EEMs. Coble (1996) and others (Mayer et al. 1999, Yamashita \& Tanoue 2003) proposed another protein-like fluorophore: $B$, due to tyrosine $\left(\lambda_{\text {ex }} / \lambda_{\text {em }}=275 / 310 \mathrm{~nm}\right)$. In the present study, Peak B has not been evaluated because it is strongly affected by the Raman scattering band of water and measurements are, therefore, not reliable.

Previous work has used only a quinine sulphate (QS) standard, valid for humic-like substances. However, 


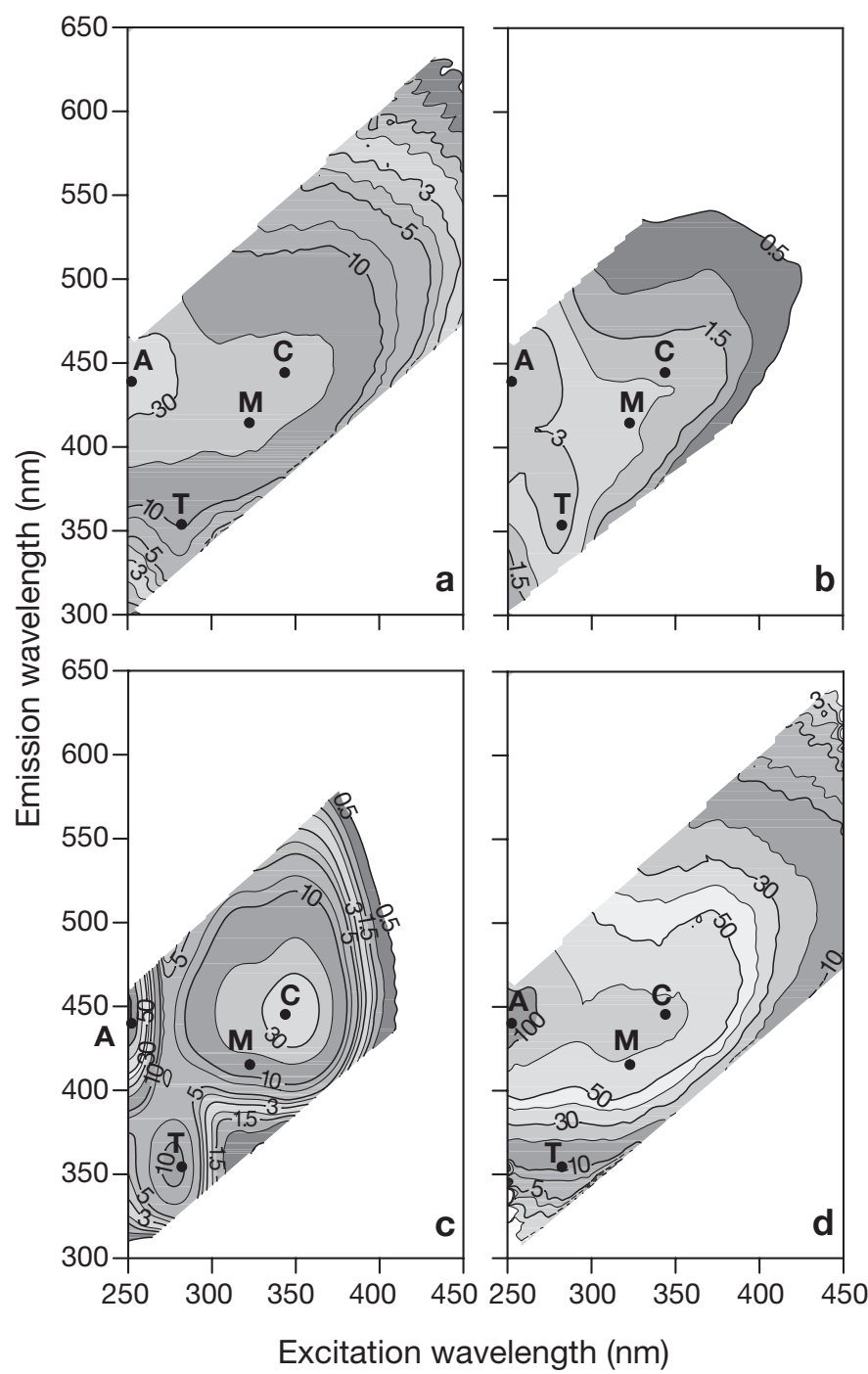

Fig. 2. Excitation/emission matrices (EEMs) of (a) the river Oitabén-Verdugo sample, (b) the surface seawater sample at Stn 00, (c) quinine sulphate (20 ppb) and tryptophan (30 ppb) in $0.05 \mathrm{M}$ sulphuric acid, and (d) commercial fulvic acid (FA, Fredricks Research Products, Laurential Soil), $333 \mu \mathrm{M} \mathrm{C}$ in seawater. The Ex/Em wavelengths of the main peaks are indicated: Peak A (general humic compounds), Peak C (terrestrial-origin humic substances), Peak M (marine-origin humic substances) and Peak T (tryptophan-like fluorescence). Fluorescence intensities are reported as fluorescence units provided by the instrument

this compound does not fluoresce in the region of the aromatic amino acids. Therefore, we propose a mixed standard of QS and tryptophan (Trp) in $0.05 \mathrm{M}$ sulphuric acid. As shown in Fig. 2c, the EEMs of the mixed standard cover all the FDOM peaks. Trp fluorescence and QS fluorescence do not interfere with each other. The mixed standard remains stable for at least 3 mo stored in the dark at $4^{\circ} \mathrm{C}$.
Due to the regularity of the Ex/Em wavelengths of the selected peaks for samples from different sites and times in the study area, we decided to carry out only discrete measurements at the selected wavelengths. Discrete DOM fluorescence analyses were executed within a few hours of sample collection; 4 replicate measurements were performed for each Ex/Em wavelength. A 4-point standard curve was prepared daily (concentrations from 0 to $20 \mathrm{ppb}$ and from 0 to $30 \mathrm{ppb}$ for QS and Trp, respectively). Fluorescence of $0.05 \mathrm{M}$ sulphuric acid in Milli-Q water was used as a blank. The equivalent concentration of each peak was determined by subtracting the average peak height from the blank height, and dividing by the slope of the standard curve. Finally, although Peaks A, C and M represent different humic compounds, they showed similar distributions $(\mathrm{r}=0.95$ for Peak A versus Peak $\mathrm{M}$ and $\mathrm{r}=$ 0.98 for Peak C versus Peak M). Therefore, only the fluorescence of Peaks $\mathrm{M}\left(\mathrm{FDOM}_{\mathrm{M}}\right)$ and $\mathrm{T}\left(\mathrm{FDOM}_{\mathrm{T}}\right)$ have been used in the present work. Fluorescence units were expressed in parts per billion equivalents of QS (ppb eq QS) for $\mathrm{FDOM}_{\mathrm{M}}$ and of Trp (ppb eq Trp) for $\mathrm{FDOM}_{\mathrm{T}}$. (Note that parts per billion equivalents of QS is identical to the quinine sulphate units [QSU] reported previously in other studies.) The precision was $\pm 0.1 \mathrm{ppb}$ QS and $\pm 0.6 \mathrm{ppb}$ Trp, respectively.

FA carbon equivalents. Assessing the contribution of humic substances to the DOC pool is not a straightforward issue, because of the highly variable composition of the 2 main fractions: the humic (HA) and fulvic (FA) acids. Our approach involved using a commercial FA (Fredricks Research Products, Laurential Soil, 38.3\% C dry weight by elemental analysis) as a standard. A FA was chosen instead of a HA, because FAs are the main component of marine humic substances, about $90 \%$ (Thurman 1985, Skoog 1995). The EEMs of a natural sample (Fig. 2a) and the commercial FA (Fig. 2d) compare well. The FA was dissolved in filtered $(0.2 \mu \mathrm{m}$ polyethersulphone filters) seawater, and filtered again after $1 \mathrm{wk}$ of incubation in the dark, to allow complete dissolution. Then, the fluorescence and DOC content of the standard were determined. The average ratio between DOC and $\mathrm{FDOM}_{\mathrm{M}}$, after several replicate measurements at different concentrations of the commercial FA, was $2.67 \pm 0.06 \mu \mathrm{M} \mathrm{C}(\mathrm{ppb} \text { eq QS) })^{-1}$.

Estimation of particulate proteins and lipids. The carbon content of particulate proteins $\left(\mathrm{C}_{\text {Prot }}\right)$ and lipids $\left(\mathrm{C}_{\text {Lip }}\right)$ was estimated by subtraction of the $\mathrm{C}$ and $\mathrm{N}$ content of particulate carbohydrates (p-CHO), chlorophyll a $(\mathrm{chl} \mathrm{a})$ and organic phosphorus compounds (POP) from the POC and PON content of the samples, using the average chemical formula of these groups of molecules provided by Fraga (2001). p-CHO was analysed by the anthrone method (Nieto-Cid et al. 2004), with a precision of $\pm 0.1 \mu \mathrm{M} \mathrm{C}$. Chl a was determined with a 
Turner Designs 10000R fluorometer after $90 \%$ acetone extraction (Yentsch \& Menzel 1963); the estimated accuracy was $\pm 0.05 \mu \mathrm{g} \mathrm{l}^{-1}$. POP was analysed by $\mathrm{H}_{2} \mathrm{SO}_{4} / \mathrm{HClO}_{4}$ digestion at $220^{\circ} \mathrm{C}$, followed by analysis of the resultant phosphate by $\mathrm{SFA}_{\text {; }}$ the precision for the entire analysis was $\pm 0.02 \mu \mathrm{M}$ P (Álvarez-Salgado 1993).

Estimation of corrected dissolved oxygen. The dissolved oxygen concentration of the samples was referred to the oxidation state of nitrate $\left(\mathrm{O}_{2 \mathrm{C}}\right)$, i.e. to a hypothetical situation in which the nitrite and ammonium of the sample were oxidised to nitrate. Since $0.5 \mathrm{~mol}$ of oxygen is necessary to oxidise $1 \mathrm{~mol}$ of nitrite to nitrate and $2 \mathrm{~mol}$ of oxygen is required to oxidise $1 \mathrm{~mol}$ of ammonium to nitrate.

$$
\mathrm{O}_{2 \mathrm{C}}=\mathrm{O}_{2}-\frac{1}{2} \times \mathrm{NO}_{2}^{-}-2 \times \mathrm{NH}_{4}^{+}
$$

This correction allows comparison of dissolved oxygen consumption and $\mathrm{N}_{\mathrm{T}}$ production independent of the inorganic nitrogen form involved in the process.

Meteorological variables. Daily Ekman transport values $\left(-Q_{\mathrm{X}}, \mathrm{m}^{2} \mathrm{~s}^{-1}\right)$ were calculated according to Wooster et al. (1976):

$$
-Q_{\mathrm{X}}=\frac{\rho_{\mathrm{air}} \cdot C \cdot|V| \cdot V_{Y}}{\rho_{\mathrm{SW}} \cdot f}
$$

where $\rho_{\text {air }}$ is the density of air, $1.22 \mathrm{~kg} \mathrm{~m}^{-3}$ at $15^{\circ} \mathrm{C}_{;} C$ is an empirical drag coefficient (dimensionless), $1.3 \times$ $10^{-3} ; f$ is the Coriolis parameter, $9.946 \times 10^{-5} \mathrm{~s}^{-1}$ at $43^{\circ}$ latitude; $\rho_{\mathrm{SW}}$ is the density of seawater, $\sim 1025 \mathrm{~kg} \mathrm{~m}^{-3}$; $|V|$ is wind speed; and $V_{y}$ is the north component of wind speed. Wind data were taken from the SeaWatch buoy, Silleiro Meteorological Observatory, at $42^{\circ} 07.2^{\prime} \mathrm{N}, 9^{\circ} 24.0^{\prime} \mathrm{W}$ (www.puertos.es). Positive values of $-Q_{\mathrm{X}}$ indicate upwelling, and downwelling is occurring when negative values are observed.

Continental runoff $\left(Q_{R}, \mathrm{~m}^{3} \mathrm{~s}^{-1}\right)$ was estimated as the sum of (1) the flow regulated by the Eiras reservoir and (2) a function of the precipitation in the drainage basin not regulated by the Eiras reservoir (Ríos et al. 1992).

\section{RESULTS}

\section{Hydrography}

Seven hydrographic periods were distinguished by Nieto-Cid et al. (2004) from May 2001 to April 2002. The periods were defined on the basis of the seasonal evolution of $-Q_{\mathrm{X}}$ and $Q_{\mathrm{R}}$ (Fig. 3a) and of the thermohaline structure of the water column (Fig. 3b,c). Briefly, the study year began during summer stratification (Period 1, 15 May to 21 August), characterised by coastal upwelling events separated by short intervals of calm. At the end of summer, a strong upwelling event (Period 2, 28 August to 18 September) raised cold, organic matter-poor and nutrient-rich ENACW to the surface layer. During Periods 1 and 2, the residual circulation of the Ría de Vigo was positive, and characterised by low continental runoff and large renewal rates. Autumn downwelling (Period 3, 25 September to 30 October) was generated by predominantly southerly winds, which coincided with high continental runoff. The transition from stratification to vertical homogenisation (Period 4, 6 to 20 November) occurred under strong northerly winds. Then, the IPC carried subtropical surface and central waters along the shelf, and promoted a reversal of the circulation pattern of the ría (Period 5, 27 November to 13 February). The subsequent winter mixing (Period 6, 20 February to 26 March) was the time of maximum vertical homogenisation, and, finally, the beginning of the spring (Period 7, 2 to 24 April) was characterised by the coexistence of coastal upwelling and incipient stratification.

\section{DOM fluorescence distributions in relation to the hydrographic conditions}

This is the first study of the seasonal variability of DOM fluorescence distributions in a coastal upwelling system. Therefore, a description of the time evolution of the vertical profiles of $\mathrm{FDOM}_{\mathrm{M}}$ and $\mathrm{FDOM}_{\mathrm{T}}$ is required. Fluorescence distributions are then compared with temperature, salinity (Fig. 3b,c), and organic (Figs. 4a,b \& 5a,b) and inorganic (Figs. 4c,d \& $5 \mathrm{c}, \mathrm{d})$ nitrogen distributions. The high correlations between DOC and DON $(\mathrm{r}=0.84, \mathrm{n}=434, \mathrm{p}<0.001)$ and between POC and PON ( $\mathrm{r}=0.98, \mathrm{n}=477, \mathrm{p}<$ 0.001) ensure that comparison of DOM fluorescence with organic carbon, instead of organic nitrogen, produces the same results.

The 2 environments sampled in this study responded differently to coastal upwelling. Therefore, it is expected that the 2 sites underwent different biogeochemical processes that can be traced with DOM fluorescence.

Mid-ría site (Stn 00)

Both $\mathrm{FDOM}_{\mathrm{M}}$ and $\mathrm{FDOM}_{\mathrm{T}}$ correlated significantly with temperature and salinity $(\mathrm{r}=0.84, \mathrm{n}=90, \mathrm{p}<$ 0.001 for Peak $M$ and $r=0.76, n=90, p<0.001$ for Peak T). Regarding the chemical parameters, FDOM M $_{M}$ correlated significantly with DON ( $\mathrm{r}=0.60, \mathrm{n}=59, \mathrm{p}<$ $0.001)$ and with ammonium $(\mathrm{r}=0.62, \mathrm{n}=90, \mathrm{p}<0.001)$,

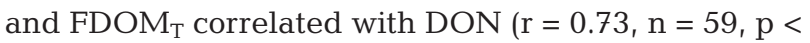
0.001), with PON ( $\mathrm{r}=0.57, \mathrm{n}=90, \mathrm{p}<0.001)$ and with nitrate $(r=-0.50, n=90, p<0.001)$. During summer 
stratification (Period 1) and upwelling (Period 2), organic nitrogen profiles were characterised by a surface maximum and a bottom minimum (Fig. 4a,b), whereas inorganic nutrient profiles were opposite (Fig. 4c,d). These profiles are typical of the upwelling season off NW Spain. At this time, the organic nitrogen-poor and nitrate-rich ENACW rise to the surface, where production and accumulation of organic nitrogen occur in the periods of calm between successive upwelling events. FDOM $\mathrm{F}_{\mathrm{M}}$ values were low in the entire water column, except at the end of July (Fig. 6a), when a surface maximum was observed due to freshwater discharge (salinity < 35.0; Fig. 3b). High surface concentrations of $\mathrm{FDOM}_{\mathrm{T}}$ coincided with low salinity and elevated DON and PON concentrations (Fig. 6b).
During upwelling episodes, $\mathrm{FDOM}_{\mathrm{T}}$ levels were low throughout the water column. Downwelling (Period 3) coincided with high runoff $\left(>300 \mathrm{~m}^{3} \mathrm{~s}^{-1}\right)$, which produced a remarkable accumulation of DON, PON and, especially, FDOM (Fig. 6a,b). During Periods 4 to 7 , FDOM $_{\mathrm{M}}$ and $\mathrm{FDOM}_{\mathrm{T}}$ displayed a similar pattern, characterised by low concentrations, except from 15 January to 15 February, when high runoff occurred again (salinity < 33.0; Fig. 3b).

Mid-shelf site (Stn 03)

Multiple regressions with temperature and salinity were less significant than those for the middle of the

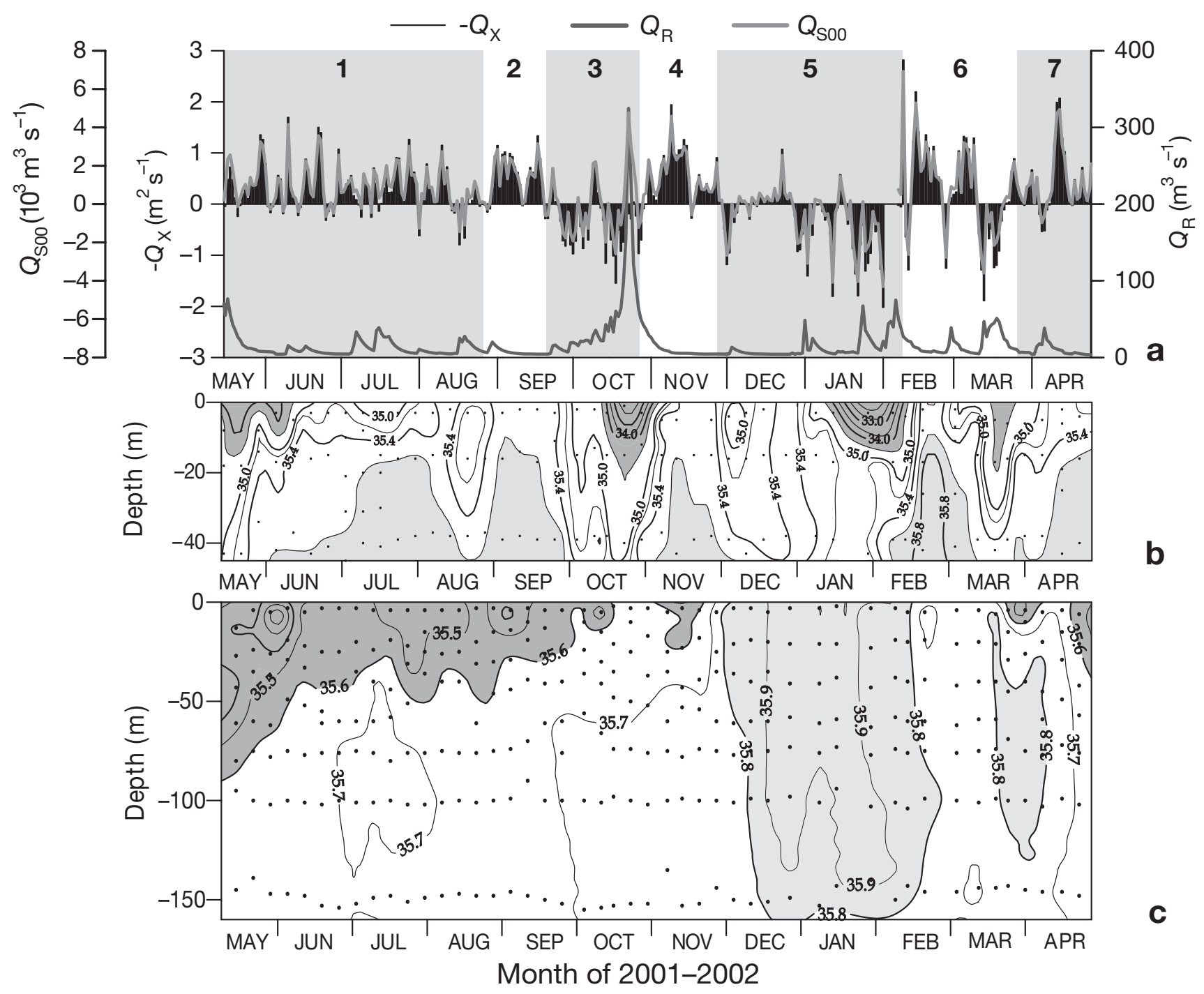

Fig. 3. (a) Time course of Ekman transport, $-Q_{\mathrm{X}}\left(\mathrm{m}^{2} \mathrm{~s}^{-1}\right)$, continental runoff, $Q_{\mathrm{R}}\left(\mathrm{m}^{3} \mathrm{~s}^{-1}\right)$ and surface water flux at Stn $00, Q_{\mathrm{S} 00}$ $\left(10^{3} \mathrm{~m}^{3} \mathrm{~s}^{-1}\right)$. The different periods are shown, designated 1 to $7 . Q_{\mathrm{S} 00}$ was calculated with the equation of Álvarez-Salgado et al. (2000): $Q_{\mathrm{S} 00}=16( \pm 4) \times 10^{-3} Q_{\mathrm{R}}-2.3( \pm 0.2) \times 10^{-3} Q_{\mathrm{X}}$. Time course of salinity at (b) Stn 00 and (c) Stn 03 during the study period 

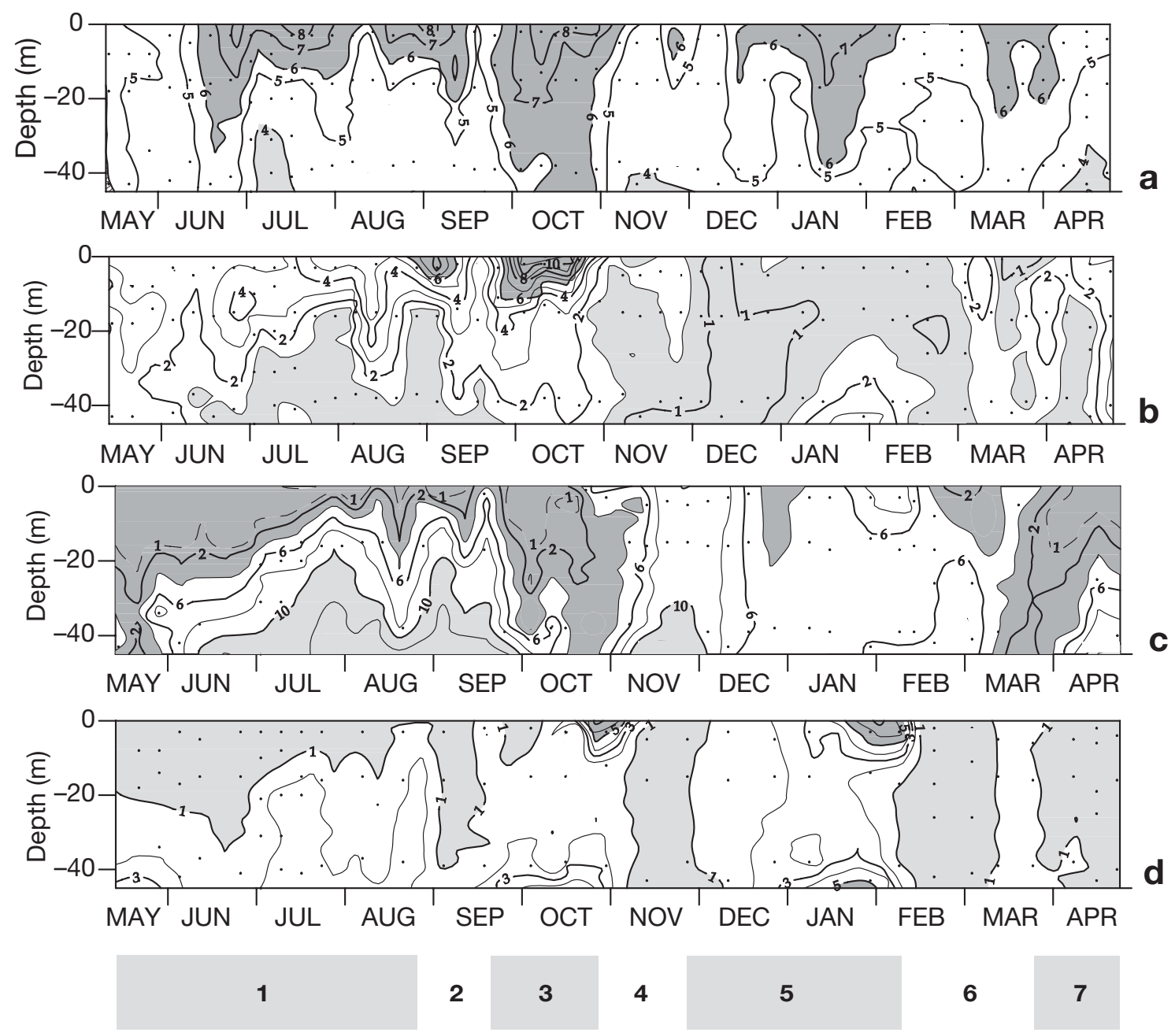

Fig. 4. Time course of (a) DON ( $\mu \mathrm{M} \mathrm{N})$, (b) PON ( $\mu \mathrm{M} \mathrm{N})$, (c) nitrate $(\mu \mathrm{M})$ and (d) ammonium $(\mu \mathrm{M})$ at Stn 00 during the study period. The different periods are shown, designated 1 to 7

ría, but they were still significant $(\mathrm{r}=0.64, \mathrm{n}=182$, $\mathrm{p}<0.001$ for $\mathrm{FDOM}_{\mathrm{M}}$ and $\mathrm{r}=0.58, \mathrm{n}=182, \mathrm{p}<0.001$ for $\mathrm{FDOM}_{\mathrm{T}}$ ). $\mathrm{FDOM}_{\mathrm{M}}$ only correlated significantly with nitrate $(\mathrm{r}=0.62, \mathrm{n}=182, \mathrm{p}<0.001)$, whereas $\mathrm{FDOM}_{\mathrm{T}}$ correlated with PON $(\mathrm{r}=0.73, \mathrm{n}=181, \mathrm{p}<0.001)$ and, to a lesser extent, with DON and nitrate $(\mathrm{r}=0.35$, $\mathrm{n}=182, \mathrm{p}<0.001$ and $\mathrm{r}=-0.24, \mathrm{n}=182, \mathrm{p}<0.001$, respectively). Higher concentrations of DON and PON (Fig. 5a,b) occurred in the surface layer during the periods of stratification $(1,2,3$ and 7$)$, whereas, during the IPC and winter-mixing periods (5 and 6), lower values were recorded. Nitrate was depleted in the photic layer and accumulated at the bottom, especially during the upwelling season (Fig. 5c). Just before the IPC (Period 5), high nitrate levels were found throughout the water column, coinciding with a DON minimum. Ammonium concentrations were low $(<0.5 \mu \mathrm{mol}$ $\mathrm{kg}^{-1}$ ) and patchily distributed (Fig. 5d). The distribution of $\mathrm{FDOM}_{\mathrm{M}}$ (Fig. 6c) was similar to nitrate, with low concentrations in the surface layer, except during September, and high concentrations at the bottom. On the other hand, $\mathrm{FDOM}_{\mathrm{T}}$ (Fig. 6d) presented a surface distribution similar to that of PON, with surface maxima during the stratification periods. Minimum DON levels occurred at the bottom, whereas in the case of PON, FDOM $\mathrm{T}$ and $\mathrm{FDOM}_{\mathrm{M}}$ high values were recorded because of the resuspension of organic-rich sediments in the bottom nepheloid layer (BNL; Figs. 5b $\& 6 \mathrm{c}, \mathrm{d})$.

Box and whisker plots are a useful tool to compare average distributions of the chemical variables on the mid-shelf. Fig. 7 compares the $\mathrm{FDOM}_{\mathrm{T}}$ profile with the PON and $\mathrm{C}_{\text {Prot }}$ profiles, and the $\mathrm{FDOM}_{\mathrm{M}}$ profile with the $\mathrm{N}_{\mathrm{T}}$ and $\% \mathrm{C}_{\mathrm{Lip}}$ profiles. Thus, $\mathrm{FDOM}_{\mathrm{T}}$ followed the distribution of fresh organic matter represented by the carbon content of proteins. In the photic layer, FDOM $\mathrm{T}_{\mathrm{T}}$ was high and very variable, whilst concentrations decreased with depth. A relative maximum was ob- 

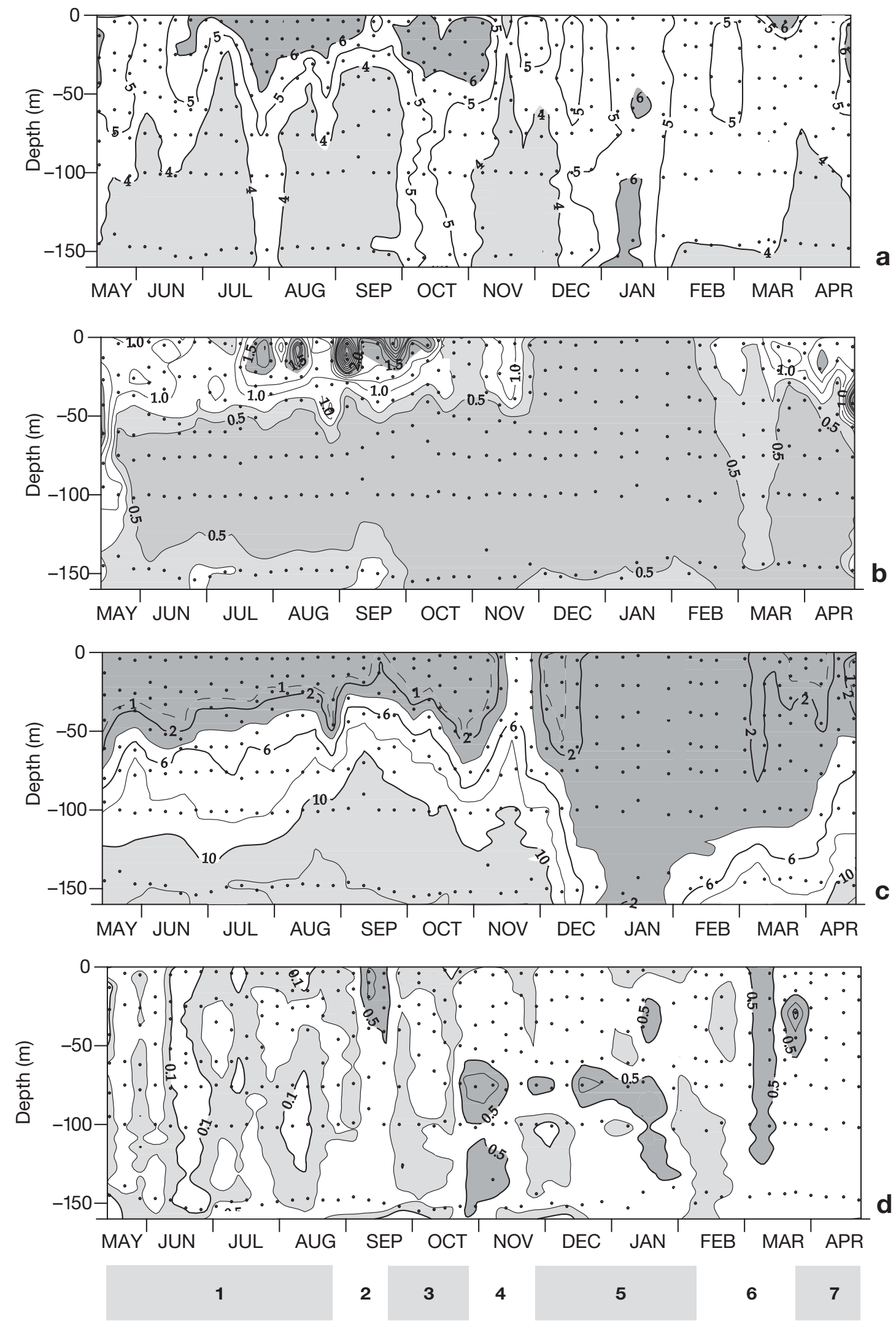

Fig. 5. Time course of (a) DON ( $\mu \mathrm{M} \mathrm{N})$, (b) PON ( $\mu \mathrm{M} \mathrm{N})$, (c) nitrate $(\mu \mathrm{M})$ and (d) ammonium $(\mu \mathrm{M})$ at Stn 03 during the study period. The different periods are shown, designated 1 to 7 

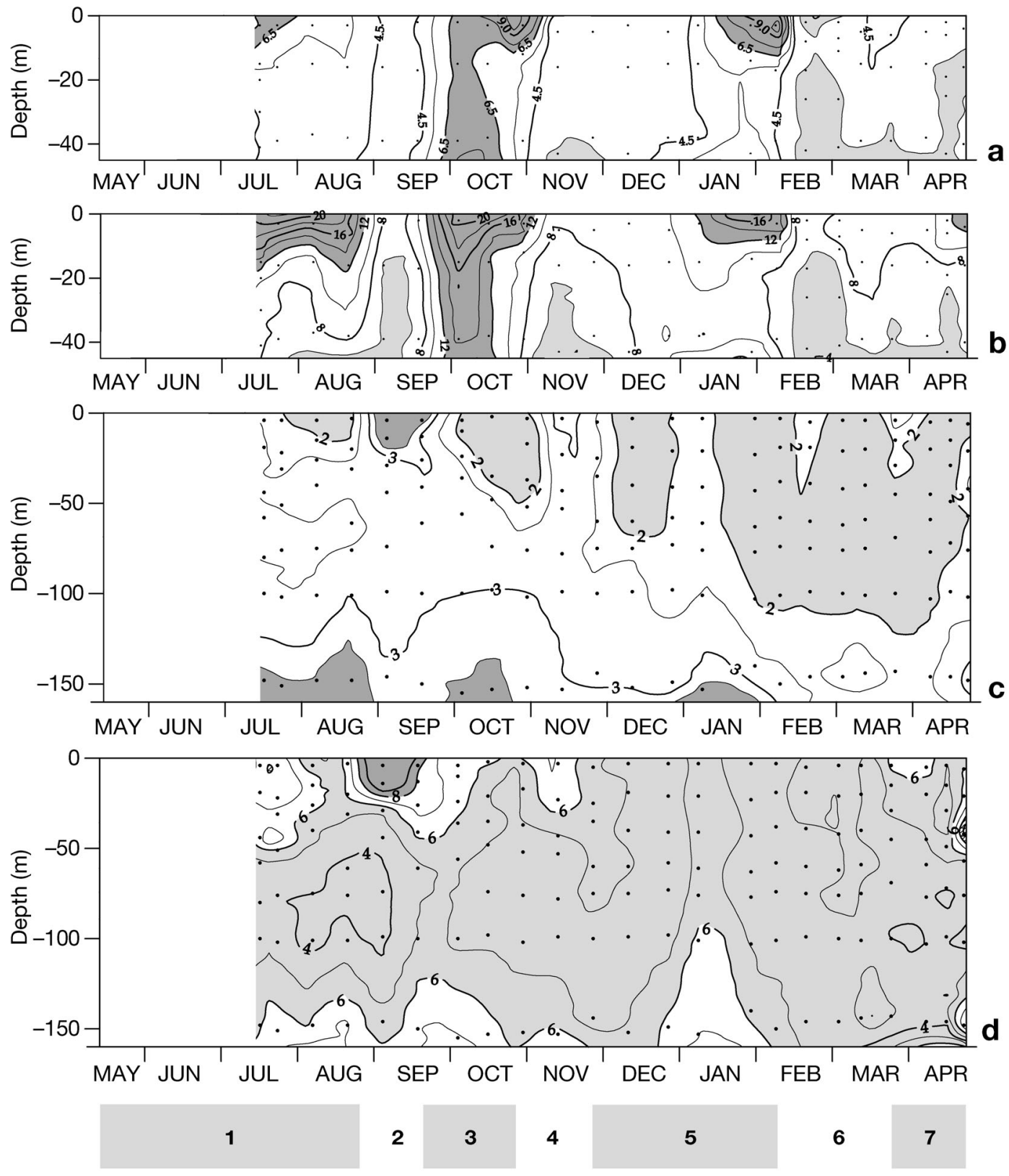

Fig. 6. Time course of (a) $\mathrm{FDOM}_{\mathrm{M}}$ (parts per billion equivalents [ppb eq] quinine sulphate [QS]) at Stn 00, (b) FDOM (ppb eq tryptophan [Trp]) at Stn 00, (c) FDOM M (ppb eq QS) at Stn 03 and (d) FDOM $_{\mathrm{T}}$ (ppb eq Trp) at Stn 03 during the study period. The different periods are shown, designated 1 to 7

served at the BNL. In contrast, $\mathrm{FDOM}_{\mathrm{M}}$ followed the distribution of the lipid contribution to the POC pool. Average $\mathrm{FDOM}_{\mathrm{M}}$ concentration increased with depth, especially at the BNL.

The contribution of humic substances to the DOC pool was assessed using the conversion factor obtained with the commercial fulvic acid. On this basis, $6-13 \%$ of surface DOC is made up of humic substances; this proportion increases gradually with depth to $11-17 \%$ at the BNL. This value was lower than at Stn 00 (13-22\%).

\section{Tracing DOM production and mineralisation}

A regression analysis involving 2 conservative parameters solves a 3-end-member mixing problem. Thus, the variation of any non-conservative parameter described by the mixing of 3 water masses can be estimated by means of a multiple linear regression of this parameter with salinity and temperature. This is the case for subsurface waters $(\mathrm{AOU}>0)$ of the NW Iberian upwelling, where the subtropical and subpolar 


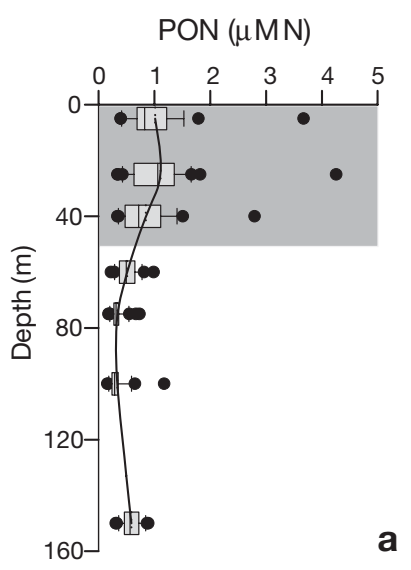

$\mathrm{FDOM}_{\mathrm{T}}$ (ppb eq Trp)
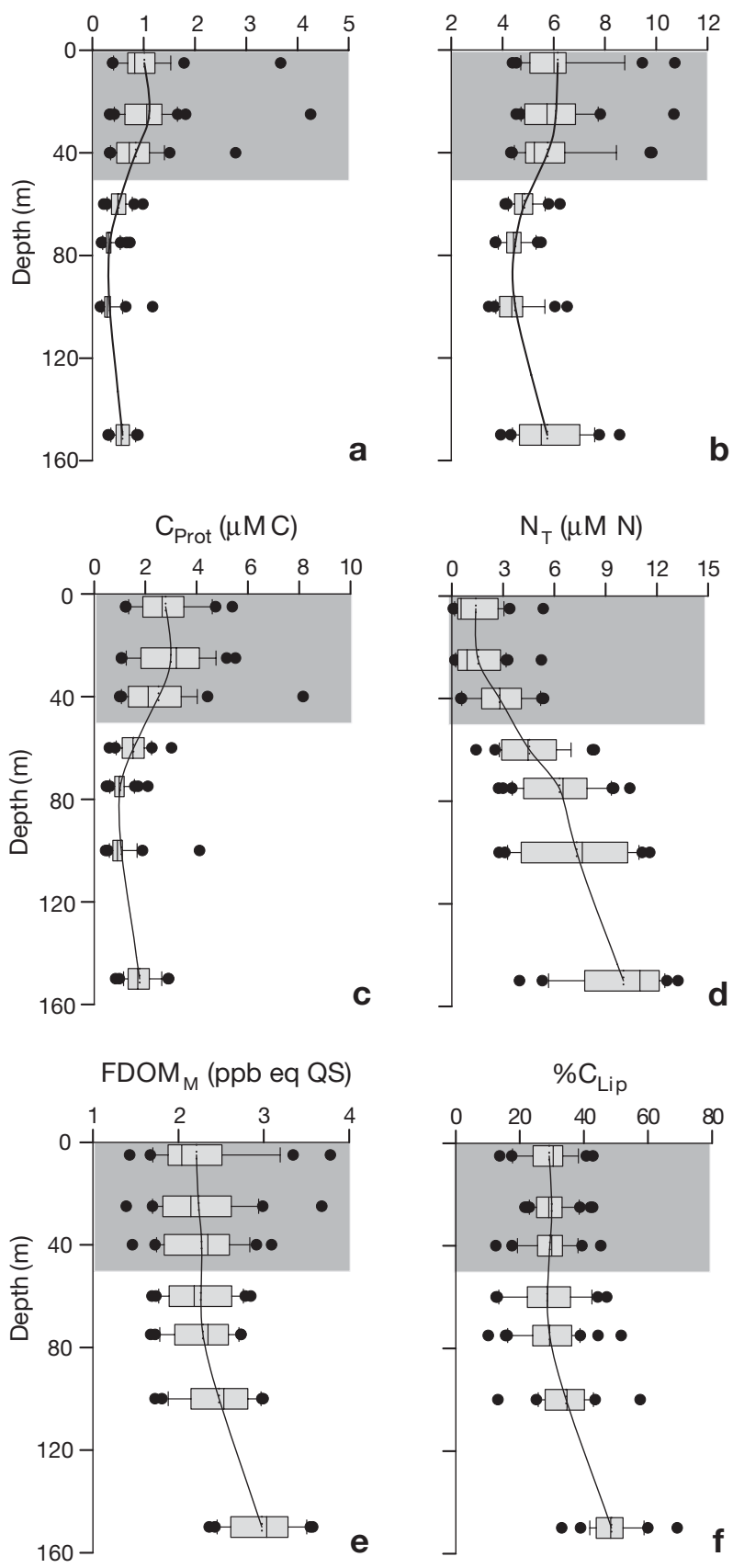

Fig. 7. Box and whisker plot of (a) PON $(\mu \mathrm{M} \mathrm{N})$, (b) FDOM (ppb eq Trp), (c) $C_{\text {Prot }}\left(\mu \mathrm{M}\right.$ C), (d) $\mathrm{N}_{\mathrm{T}}(\mu \mathrm{M} \mathrm{N})$, (e) $\mathrm{FDOM}_{\mathrm{M}}$ (ppb eq QS) and (f) $\% \mathrm{C}_{\text {Lip }}$ for the whole data set at Stn 03. Fifty percent of the data are included within the limit of the boxes and the caps represent the 10th and 90th percentiles. Solid lines represent the average profiles. For abbreviations see Fig. 6

branches of ENACW mix with coastal waters. An anomaly $(a Y)$ can be defined for each chemical parameter $(Y)$ :

$$
a Y=Y-a_{0}-a_{1} \times S-a_{2} \times T
$$

where $a_{0}, a_{1}$ and $a_{2}$ are the coefficients of the linear multiple regression of $Y$ with salinity and temperature; $a Y$ retains only the variability associated with the biogeochemical processes that occur in waters of AOU $>0$.

Once the effect of water-mass mixing was removed applying Eq. (3), both sites showed good correlations

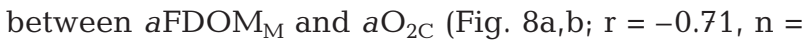
64, p $<0.001$ for Stn 00 and $\mathrm{r}=-0.76, \mathrm{n}=153, \mathrm{p}<0.001$ for Stn 03) and similar slopes (0.024 \pm 0.003 and $0.025 \pm$ $0.002 \mathrm{ppb}$ eq QS $\mu \mathrm{M}^{-1} \mathrm{O}_{2 \mathrm{C}}$, respectively; Model II, Sokal \& Rohlf 1995). Using the conversion factor of FDOM $_{\mathrm{M}}$ to DOC obtained with the commercial fulvic acid, every mol of dissolved oxygen consumed would generate $0.066 \pm 0.009 \mathrm{~mol}$ of humic carbon. Assuming a ratio of $1.42 \mathrm{~mol} \mathrm{O}_{2} \mathrm{~mol}^{-1} \mathrm{C}$ for the remineralisation of organic matter in oxic conditions (Anderson 1995, Fraga 2001), then $9 \pm 1 \%$ of the organic carbon potentially mineralised directly to $\mathrm{CO}_{2}$ was in fact transformed into humic substances, as a by-product of the oxidation of organic matter.

On the other hand, ${ } \mathrm{FDOM}_{\mathrm{T}}$ correlated significantly with $\mathrm{aC}_{\text {Prot }}$ (Fig. 8c, $\mathrm{d}_{i} \mathrm{r}=0.61, \mathrm{n}=79, \mathrm{p}<$ 0.001 for $\operatorname{Stn} 00$, and $r=0.57, \mathrm{n}=163, \mathrm{p}<0.001$ for Stn 03), i.e. the most labile organic material. In this case, the 2 environments showed marked differences: whereas in the middle ría the slope was $1.2 \pm$ $0.2 \mathrm{ppb}$ eq $\operatorname{Trp} \mu \mathrm{M}^{-1} \mathrm{C}$, in the middle shelf it reduced to $0.5 \pm 0.1 \mathrm{ppb}$ eq $\operatorname{Trp} \mu \mathrm{M}^{-1} \mathrm{C}$ (Model II, Sokal \& Rohlf 1995).

\section{Seasonal accumulation}

The 2-layered circulation of the Ría de Vigo (Fig. 9) allows us to estimate the net accumulation of organic matter at different sites using a simple mixing model. First, the net increase of FDOM in the surface layer of Stn 00 or Stn 03 can be calculated as the FDOM excess of the surface layer $\left(\Delta \mathrm{FDOM}_{\mathrm{S}}\right)$ compared with the expected FDOM from the linear mixing of the freshwater and ENACW end members:

$$
\begin{aligned}
& \Delta \text { FDOM }_{\mathrm{S}}= \\
& \text { FDOM }_{\mathrm{S}}-\left(\frac{S_{\mathrm{S}}}{S_{\mathrm{O}}} \cdot \mathrm{FDOM}_{\mathrm{O}}+\frac{S_{\mathrm{O}}-S_{\mathrm{S}}}{S_{\mathrm{O}}} \cdot \mathrm{FDOM}_{\mathrm{F}}\right)
\end{aligned}
$$

where FDOM $\mathrm{S}_{\mathrm{S}}$ and $S_{\mathrm{S}}$ are the FDOM and salinity of the surface layer, FDOM $_{\mathrm{O}}$ and $\mathrm{S}_{\mathrm{O}}$ are the average FDOM and salinity of the ENACW end member, and FDOM is the FDOM of the freshwater end member. Similar equations can be written for the 2 DOM fluorophores and the other chemical variables.

The ENACW end member was sampled during the same period as Stn 00 and Stn 03 on the continental slope off the Ría de Vigo (4207.8' N, 9³0.0' W, $1200 \mathrm{~m}$ 

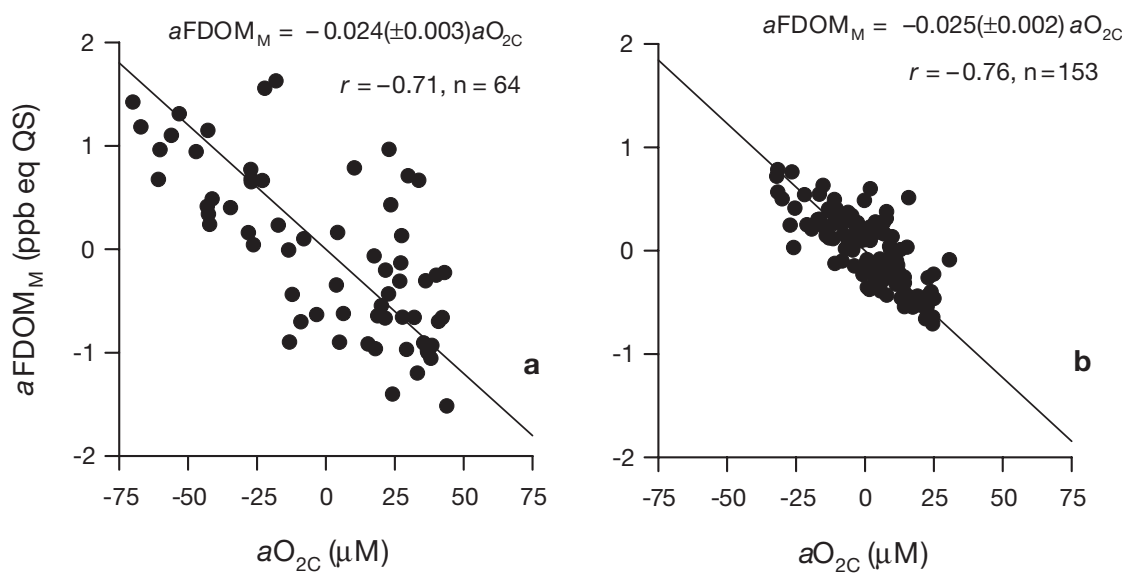

ratios for seawater were 4.0 to $6.6 \mathrm{mg}$ eq QS $\mathrm{mmol}^{-1} \mathrm{C}$ and 10 to $14 \mathrm{mg}$ eq $\operatorname{Trp} \mu \mathrm{mol}^{-1} \mathrm{C}$, respectively. At the Eiras reservoir, the ratios reached values of $30 \pm 9 \mathrm{mg}$ eq $\mathrm{QS} \mu \mathrm{mol}^{-1} \mathrm{C}$ and $30 \pm 3 \mathrm{mg}$ eq Trp $\mu \mathrm{mol}^{-1} \mathrm{C}$. Other authors have also found an increase in the FDOM/DOC ratio with decreasing salinity (Callahan et al. 2004, Del Vecchio \& Blough 2004). The seasonal cycles of the humic- and protein-like fluorophores in the freshwater end member were slightly different. The $\mathrm{FDOM}_{\mathrm{T}}$ concentration was low during the spring and high during the autumn, when continental runoff was large and high loads of labile materials of terrestrial plant origin occur. On the other hand, FDOM $_{M}$ was maximal in autumn and winter and decreased to minimal concentrations in spring and summer. The large contribution of terrestrial materials in autumn and the photochemical degradation of humic substances, widely reported in the literature (see Miller \& Moran 1997, Vähätalo \& Wetzel 2004) and observed in the study area (M. Nieto-Cid et al. unpubl. data), are probably the reasons behind this seasonal evolution.

Second, the net increase of fluorescent DOM in the bottom layer of Stn 00 or Stn 03 can be estimated as the FDOM excess of the bottom sample

depth; Stn 05 in Fig. 1). Although ENACW consists of 2 branches, a unique end member was considered in these rough calculations, because the specific salinity of the ENACW upwelled on each sampling date, resulting from the mixture of the subtropical and subpolar branches, was computed.

The river Oitabén-Verdugo is the freshwater end member. The concentrations of the chemical parameters measured at the Eiras reservoir $(\mathrm{S}=0.00)$ were considered. Rivers are sources of the 2 types of fluorophores (Mayer et al. 1999, Chen et al. 2002), but especially of the humic substances. The river inputs were responsible for the surface FDOM maxima recorded under conditions of large continental runoff. This is due to the elevated inherent fluorescence of freshwater; typical values at the Eiras reservoir were $27 \mathrm{ppb}$ eq Trp and $26 \mathrm{ppb}$ eq QS, but differences with seawater are more apparent if FDOM/DOC ratios are compared. FDOM $\mathrm{M}_{\mathrm{M}}$ /DOC and $\mathrm{FDOM}_{\mathrm{T}} / \mathrm{DOC}$
$\left(\Delta \mathrm{FDOM}_{\mathrm{B}}\right)$ compared with the expected FDOM from the linear mixing of the surface sample of Stn 00 or Stn 03 with the ENACW end member:

$$
\begin{aligned}
& \Delta \text { FDOM }_{\mathrm{B}}= \\
& \mathrm{FDOM}_{\mathrm{B}}-\left(\frac{S_{\mathrm{O}}-S_{\mathrm{B}}}{S_{\mathrm{O}}-S_{\mathrm{S}}} \cdot \mathrm{FDOM}_{\mathrm{S}}+\frac{S_{\mathrm{B}}-S_{\mathrm{S}}}{S_{\mathrm{O}}-S_{\mathrm{S}}} \cdot \mathrm{FDOM}_{\mathrm{O}}\right)
\end{aligned}
$$

where FDOM $\mathrm{B}_{\mathrm{B}}$ and $\mathrm{S}_{\mathrm{B}}$ are the FDOM and salinity at the bottom of Stn 00 or Stn 03. The same equation can be written for the 2 DOM fluorophores and the other chemical variables.

Third, the net increase of fluorescent DOM in the ría (from San Simon Bay to Stn 00) and on the shelf (from San Simon Bay to Stn 03) can be estimated as the accumulation of FDOM in the surface sample ( $\delta$ FDOM) compared with the expected FDOM from the linear mixing of the surface sample of Stn 00 or Stn 03 with the bottom sample of the same station and the freshwater end member: 


$$
\begin{aligned}
& \delta \mathrm{FDOM}= \\
& \mathrm{FDOM}_{\mathrm{S}}-\left(\frac{S_{\mathrm{S}}}{S_{\mathrm{B}}} \cdot \mathrm{FDOM}_{\mathrm{B}}+\frac{S_{\mathrm{B}}-S_{\mathrm{S}}}{S_{\mathrm{B}}} \cdot \mathrm{FDOM}_{\mathrm{F}}\right)
\end{aligned}
$$

The accumulation on the outer shelf (from Stn 00 to Stn 03) can be estimated by subtraction of the calculation for the shelf minus the calculation for the ría.

Fig. 9 shows the net DOC, POC, DON, PON, $\mathrm{N}_{\mathrm{T}}$ and $\mathrm{FDOM}_{\mathrm{T}}$ excesses in the upper and bottom layers at both sites, and the corresponding accumulations in the ría and on the outer shelf. In general, surface and bottom values are positive for all the organic-matter parameters. Only $\mathrm{FDOM}_{\mathrm{M}}$ experienced a deficit in the surface layer at Stn 03. In contrast, the trends in nutrient salts were negative at the surface (net deficit) and positive at the bottom (net excess).

The $\mathrm{N}_{\mathrm{T}}$ deficit was larger in the surface layer of the shelf, whereas the DOC, DON, POC, PON and $\mathrm{FDOM}_{\mathrm{T}}$ excesses were larger in the surface layer of the ría. For the bottom layer, larger excesses occurred in the ría for all variables except for DON and $\mathrm{FDOM}_{\mathrm{T}}$ (not significantly different at either site). Maximum surface excesses occurred in the ría during the downwelling period: $\triangle \mathrm{DOC}=38 \mu \mathrm{M} \mathrm{C}, \Delta \mathrm{POC}=$ $46 \mu \mathrm{M} \mathrm{C}, \Delta \mathrm{DON}=3.7 \mu \mathrm{M} \mathrm{N}, \Delta \mathrm{PON}=6.9 \mu \mathrm{M} \mathrm{N}$, $\Delta \mathrm{FDOM}_{\mathrm{M}}=5.6 \mathrm{ppb}$ eq QS and $\Delta \mathrm{FDOM}_{\mathrm{T}}=14.1 \mathrm{ppb}$ eq Trp.

Organic matter accumulated in the ría $(\delta \mathrm{FDOM}>0)$ was partially consumed on the shelf $(\delta \mathrm{FDOM}<0)$. It is possible to calculate the net production or consumption of any chemical parameter in the ría using the calculated renewal rates for each period (Table 2). The highest production rates of organic carbon and nitrogen occurred during the upwelling period, and coincided with maximum nutrient consumption. However, maximum $\mathrm{FDOM}_{\mathrm{T}}$ production rates took place during summer stratification

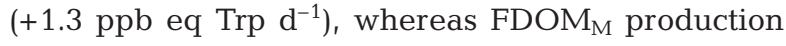
rates did not show significant variations over the study year. In the bottom layer, nutrients were produced at faster rates during summer stratification and upwelling conditions (Periods 1 and 2).

In the surface layer, nutrient consumption rates correlated significantly with DON ( $\mathrm{r}=-0.94, \mathrm{n}=7$, $\mathrm{p}<0.001)$, PON ( $\mathrm{r}=-0.79, \mathrm{n}=7, \mathrm{p}<0.05)$ and $\mathrm{FDOM}_{\mathrm{T}}(\mathrm{r}=-0.77, \mathrm{n}=7, \mathrm{p}<0.05)$ production rates. Nevertheless, in the bottom layer, only $\mathrm{FDOM}_{\mathrm{M}}$ production rates correlated significantly with nutrient production rates $(\mathrm{r}=0.85, \mathrm{n}=7, \mathrm{p}<0.01)$. The contribution of humic substances to the net accumulation of DOC was larger in the bottom than in the surface ( 90 to $15 \%)$ layer. These percentages were estimated considering the conversion factor of $\mathrm{FDOM}_{\mathrm{M}}$ to DOC obtained with the commercial fulvic acid.
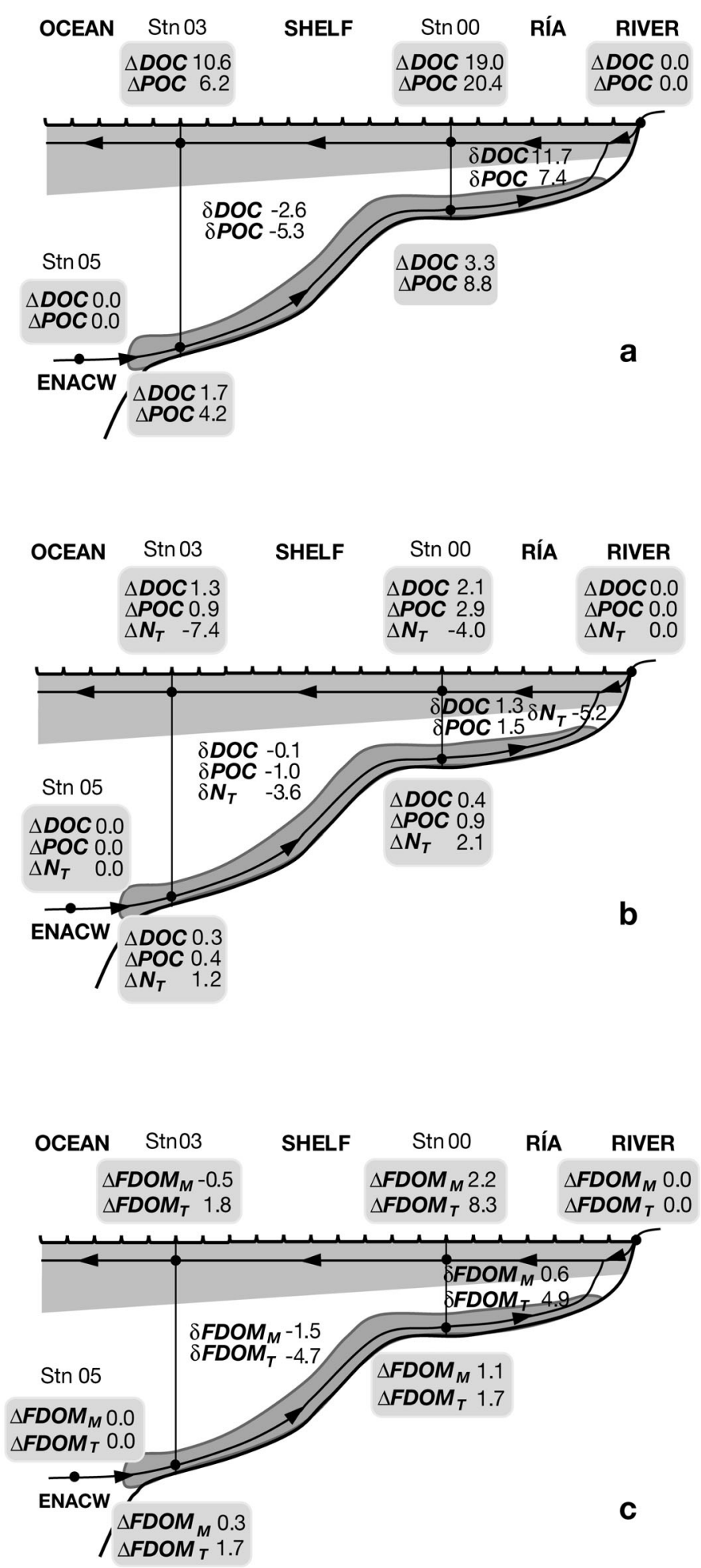

Fig. 9. Scheme of the exchange of water between the ría, the shelf and the adjacent ocean $(\Delta:$ surface and bottom net excesses of the chemical parameters; $\delta$ : net accumulations in the ría and the outer shelf). Plots include (a) DOC ( $\mu \mathrm{M} \mathrm{C}$ ) and POC $(\mu \mathrm{M} \mathrm{C}),(b) \mathrm{DON}(\mu \mathrm{M} \mathrm{N})$, PON $(\mu \mathrm{M} \mathrm{N})$ and $\mathrm{N}_{\mathrm{T}}$ $(\mu \mathrm{M} \mathrm{N})$ and (c) $\mathrm{FDOM}_{\mathrm{M}}$ (ppb eq QS) and $\mathrm{FDOM}_{\mathrm{T}}$ (ppb eq Trp). For abbreviations see Fig. 6 
Table 2. Net production rates of DOC $\left(\mu \mathrm{M} \mathrm{C} \mathrm{d}^{-1}\right), \operatorname{POC}\left(\mu \mathrm{M} \mathrm{C} \mathrm{d}^{-1}\right), \mathrm{DON}\left(\mu \mathrm{M} \mathrm{N} \mathrm{d}^{-1}\right), \operatorname{PON}(\mu \mathrm{M} \mathrm{N} \mathrm{d}), \mathrm{N}_{\mathrm{T}}\left(\mu \mathrm{M} \mathrm{N} \mathrm{d} \mathrm{d}^{-1}\right), \mathrm{FDOM}_{\mathrm{M}}$ (ppb eq QS d ${ }^{-1}$ ) and $\mathrm{FDOM}_{\mathrm{T}}$ (ppb eq Trp $\mathrm{d}^{-1}$ ) at the bottom and surface layer of Stn 00 for the annual cycle and the main periods. Considering $Q_{\mathrm{S} 00}$ and the volume of the ría from the inner reaches to Stn $00\left(0.53 \mathrm{~km}^{3}\right)$, the annual average renewal rate was $9 \pm 2 \% d^{-1}$ (Nieto-Cid et al. 2004). For abbreviations see Fig. 6

\begin{tabular}{|c|c|c|c|c|c|c|c|c|c|c|c|c|c|c|}
\hline \multirow{2}{*}{$\begin{array}{l}\text { Period } \\
\text { Annual cycle }\end{array}$} & \multicolumn{2}{|c|}{$\begin{array}{c}\text { DOC } \\
\text { Surf. Bott. }\end{array}$} & \multicolumn{2}{|c|}{$\begin{array}{c}\text { POC } \\
\text { Surf. Bott. }\end{array}$} & \multicolumn{2}{|c|}{$\begin{array}{c}\text { DON } \\
\text { Surf. Bott. }\end{array}$} & \multicolumn{2}{|c|}{$\begin{array}{c}\text { PON } \\
\text { Surf. Bott. }\end{array}$} & \multicolumn{2}{|c|}{$\begin{array}{c}\mathrm{N}_{\mathrm{T}} \\
\text { Surf. Bott. }\end{array}$} & \multicolumn{2}{|c|}{$\begin{array}{l}\text { FDOM }_{M} \\
\text { Surf. Bott. }\end{array}$} & \multicolumn{2}{|c|}{$\begin{array}{l}\text { FDOM }_{T} \\
\text { Surf. Bott }\end{array}$} \\
\hline & 1.1 & 0.3 & 0.7 & 0.8 & 0.1 & 0.0 & 0.1 & 0.1 & -0.5 & 0.2 & 0.1 & 0.1 & 0.5 & 0.2 \\
\hline 1 Summer stratification & 2.2 & 0.3 & 1.7 & 1.0 & 0.3 & 0.0 & 0.2 & 0.1 & -1.5 & 0.6 & 0.1 & 0.2 & 1.3 & 0.3 \\
\hline 2 Upwelling & 4.2 & 0.3 & 4.5 & 2.0 & 0.5 & 0.0 & 0.7 & 0.3 & -1.9 & 0.7 & 0.1 & 0.2 & 0.7 & 0.4 \\
\hline 3 Downwelling & 0.3 & 0.1 & 0.5 & 0.1 & 0.0 & 0.0 & 0.1 & 0.0 & 0.0 & 0.0 & 0.0 & 0.0 & 0.1 & 0.1 \\
\hline 5 IPC period & 0.4 & 0.2 & -0.3 & 0.6 & 0.0 & 0.0 & 0.0 & 0.1 & 0.1 & 0.0 & 0.1 & 0.0 & 0.2 & 0.1 \\
\hline 6 Winter mixing & 0.5 & 0.7 & -0.4 & 1.5 & 0.1 & 0.1 & 0.0 & 0.2 & -0.1 & -0.2 & 0.1 & 0.1 & 0.4 & 0.2 \\
\hline 7 Spring & 2.0 & 0.3 & 0.5 & 2.0 & 0.2 & 0.1 & 0.1 & 0.3 & -1.3 & 0.2 & 0.0 & 0.2 & 0.8 & 0.3 \\
\hline
\end{tabular}

\section{DISCUSSION}

\section{DOM fluorescence as a tracer for microbial processes}

As in other marine environments (Hayase et al. 1987, 1988, Chen \& Bada 1992, Determann et al. 1996), $\mathrm{FDOM}_{\mathrm{M}}$ concentrations were low at the surface and increased with depth. This gradient is created by photodegradation in the surface layer and humification throughout the water column, especially at the BNL and in sediments (Skoog et al. 1996, Burdige et al. 2004). In this sense, the good correlation between $\mathrm{FDOM}_{\mathrm{M}}$ and nutrient salts in shelf bottom waters suggests that humification was tightly coupled to mineralisation, indicating that the formation of fluorescent marine humic substances goes together with the decomposition of settling particles in the water column (Hayase et al. 1987, 1988, Hayase \& Shinozuka 1995). Chen \& Bada (1992) suggested that the bacteria responsible for the regeneration of nutrients are simultaneously producing refractory compounds from biologically labile components.

A substantial difference between the 2 study sites was that $\mathrm{FDOM}_{\mathrm{M}}$ correlated better with reduced nitrogen (DON and ammonium) in the ría and with oxidised nitrogen (nitrate) on the shelf. This suggests that humic substances are not produced during the mineralisation of organic nitrogen, but during the oxidation of organic carbon. Particularly, some authors point to the degradation of lipids, nitrogen-free biomolecules, as an origin for humic substances (Kieber et al. 1997). In our case, $\mathrm{FDOM}_{\mathrm{M}}$ and $\% \mathrm{C}_{\text {Lip }}$ followed the same trend, showing lipids to be a possible precursor of humic compounds.

The contributions of humic substances to the DOC pool estimated in this work ( 6 to $22 \%$ ) were similar to the numbers obtained by Obernosterer \& Herndl (2000) in the Adriatic Sea $(15 \pm 7 \%)$ and lower than those in the North Sea $(43 \pm 7 \%)$, a marine ecosystem more affected by terrestrial contributions. The percentage of conversion of degradable organic carbon into humic substances was $\sim 10 \%$, in both the ría and on the shelf. This number is much higher than the $1 \%$ obtained by Hayase \& Shinozuka (1995) for mid-depth waters $(300$ to $1000 \mathrm{~m})$ of the Central Equatorial Pacific. However, these authors suggested that the ratio of fluorescent organic matter to total dissolved organic substances should be much higher than $1 \%$. In addition, the oceanic site sampled by Hayase \& Shinozuka (1995) is not comparable to a coastal upwelling system, where more intense humification processes are expected. Moreover, the effects of thermohaline parameters were eliminated from the correlation between $\mathrm{FDOM}_{\mathrm{M}}$ and oxygen in this work, but not in the work of Hayase \& Shinozuka (1995). This may also be the reason behind the low slopes of the correlations of $\mathrm{FDOM}_{\mathrm{M}}$ with nitrate, phosphate, silicate and $\mathrm{O}_{2 \mathrm{C}}$ on the Iberian margin $(0.14 \pm 0.01,2.4 \pm 0.2,0.37 \pm 0.03$

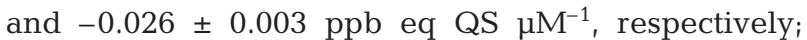
Model II) compared with the Central Equatorial Pacific (Hayase \& Shinozuka 1995) and the North Pacific (Hayase et al. 1988).

Although $\mathrm{FDOM}_{\mathrm{T}}$ relates directly with the fluorescence of aromatic amino acids, Yamashita \& Tanoue (2003) demonstrated that it could be a useful indicator of the dynamics of DFAA in general. The significant correlation with suspended proteins $(\mathrm{r}>0.57, \mathrm{p}<$ 0.001) also supports this statement. Since DFAA are liberated during phytoplankton exudation, cell autolysis and zooplankton grazing (Nagata 2000), FDOM can be used in future studies to trace these processes, which occur preferentially in the surface layer. The accumulation of $\mathrm{FDOM}_{\mathrm{T}}$ observed in the BNL could be related to an enhancement of the in situ production and/or to the release of the DFAA accumulated in the porewaters of pelagic sediments (Coble 1996, Mayer et al. 1999), which exceed the rate of consumption of these labile molecules. 


\section{Production and consumption rates of fluorescent DOM}

Since marine humic substances are microbiologically generated in the lower layer and photodegraded in the upper layer (Chen \& Bada 1992), the net excess of $\mathrm{FDOM}_{\mathrm{M}}$ should be positive near the bottom and negative at the surface. However, FDOM $_{M}$ was produced in the surface layer of the ría at an average net rate of $0.2 \mathrm{ppb}$ eq $\mathrm{QS} \mathrm{d} \mathrm{d}^{-1}$, probably because humification processes in San Simón Bay exceed photodegradation. San Simón Bay, in the innermost part of the Ría de Vigo, is a shallow basin with an average depth of $4 \mathrm{~m}$, where the ría receives most of its continental inputs. This bay is strongly affected by the tidal cycle: $>40 \%$ of the basin sediments are exposed to the atmosphere during low tides (Gilcoto 2004). Biogenic materials entering San Simón Bay undergo strong biochemical processes, able to modify the chemical composition of the water flowing into the ría, especially due to the activity of the marine angiosperm Zostera (Niell 1977). The elevated $\mathrm{pCO}_{2}$ level (>600 $\mu \mathrm{atm}$ ) of the surface waters of San Simon Bay is a clear indication of the strong mineralisation processes that occur there (Gago et al. 2003).

The largest excess of fluorescent DOM in the surface layer occurred during stratification periods in the ría and on the shelf, whilst the largest excess in the bottom layer was recorded during the downwelling period, in response to the reversal of the positive residual circulation pattern. Fluorescent DOM accumulates in the BNL, in agreement with the statement of Mayer et al. (1999) and Burdige et al. (2004) that sediments provide a source of protein- and humic-like fluorescence. Seasonal changes in $\mathrm{FDOM}_{\mathrm{T}}$, DOC, POC, DON and PON surface production were tied to the changes in nutrient consumption, pointing again to the close relationship between the production of $\mathrm{FDOM}_{\mathrm{T}}$ and fresh (labile) materials. However, net production of nutrients at the bottom correlated significantly only with $\mathrm{FDOM}_{\mathrm{M}}$, suggesting a coupling between mineralisation and humification processes at the BNL. Despite intense mineralisation processes in bottom shelf waters $\left(\delta \mathrm{N}_{\mathrm{T}} \gg 0\right)$, which would produce an accumulation of $\mathrm{FDOM}_{\mathrm{M}}$, the balance for the whole water column indicates a large deficit of humic-like fluorescence $\left(\delta \mathrm{FDOM}_{\mathrm{M}}=-1.5 \mathrm{ppb}\right.$ eq QS) and, consequently, the importance of photodegradation of humic substances in the surface layer on the shelf.

Information on the production and accumulation of DOM in upwelling systems is scarce and practically restricted to previous studies in the NW Iberian upwelling system. Doval et al. (1997) estimated the accumulation of DOC and DON in the Ría de Vigo during the upwelling season of 1995 . Their values $(21 \mu \mathrm{M} \mathrm{C}$ and $1.7 \mu \mathrm{M} \mathrm{N}$, respectively) were similar to those obtained in this work for the upwelling period $(20 \mu \mathrm{M}$ C and $2.2 \mu \mathrm{M} N$, respectively). Concomitantly, Álvarez-Salgado et al. (1999) calculated a DOC production rate during the upwelling season in the inner ría of $4.4 \mu \mathrm{M} \mathrm{C} \mathrm{d}^{-1}$, which is not significantly different from the $4.2 \mu \mathrm{M} \mathrm{C} \mathrm{d}^{-1}$ obtained in this work. They also found that surface waters of the outer ría produced 1.3 $\mu \mathrm{M} \mathrm{C} \mathrm{d}^{-1}$, whereas the shelf acted simply as a retention volume, where DOM production and consumption were in equilibrium (net production $=0.0 \mu \mathrm{M}$ $\mathrm{C} \mathrm{d}^{-1}$ ). The total DOC excess from the inner ría to the shelf computed by Álvarez-Salgado et al. (1999) was $8 \mu \mathrm{M} \mathrm{C}$, which coincides with the number obtained in this study.

Comparison of the net accumulation of dissolved and particulate organic matter in the ría and on the shelf (with respect to the whole water column) produces a different view of the carbon and nitrogen cycles in NW Iberian shelf waters. Up to $40 \%$ of the net production of organic carbon and nitrogen in the inner ría was consumed on the shelf. The remaining $60 \%$ was exported to the adjacent ocean, probably in the recurrent upwelling filament off the Rías Baixas (ÁlvarezSalgado et al. 2001b). Preferential consumption of the particulate fraction occurred: $70 \%$ of the POC was consumed compared with only $20 \%$ of the DOC. The reason behind this difference is the gravitational sinking on the shelf of the POC exported from the rías, which experiences strong mineralisation processes in the BNL. Intense nutrient mineralisation in shelf bottom waters at the expense of the materials exported from the rías has been suggested by Tenore et al. (1982), Álvarez-Salgado et al. (1997) and Prego et al. (1997). However, this is the first time that the proportion of the organic matter exported from the ría that is mineralised on the shelf has been quantified. On the other hand, DOC preferentially crosses the surface layer of the shelf to be exported to the adjacent ocean. Consequently, whereas the average DOC/POC ratio of the material accumulated in the ría was $1.6(=11.7 / 7.4$; $60 \%$ DOC, $40 \%$ POC), the ratio of the material exported to the adjacent ocean was $4.3(=[11.7$ to $2.6] /[7.4$ to 5.3$] ; 80 \%$ DOC, $20 \%$ POC). The contribution of POC to the organic matter accumulated in the ría during the annual cycle was comparable with the $45 \%$ obtained by Gago et al. (2003) for the same system in 1997. However, for the case of the shelf, the $20 \%$ of POC export obtained in this study, contrasts with the $50 \%$ found by Álvarez-Salgado et al. (2001b) in the upwelling filament of the Rías Baixas, although their numbers refer exclusively to a short period in August 1998.

The $\mathrm{C} / \mathrm{N}$ molar ratio of the organic matter accumulated in the ría ranges from an average of 5.0 for the 
particulate material to 9.0 for the dissolved material. The average $\mathrm{C} / \mathrm{N}$ ratio of the products of synthesis and early degradation of marine phytoplankton is 6.7 (Anderson 1995, Fraga 2001). Therefore, the accumulated particulate material is more labile (N-richer) than the dissolved material (N-poorer). This is also in agreement with the preferential consumption of particulate material on the shelf. Although only $20 \%$ of the bulk DOC exported to the shelf was respired, this is not the case for the labile fraction of the DOM represented by FDOM $_{\mathrm{T}}$ : up to $95 \%$ of the DFAA exported from the ría was consumed on the shelf. Since the net average deficit of DON in shelf waters $(\delta \mathrm{DON})$ was only $-0.1 \mu \mathrm{M} N$, most of it was probably due to the net consumption of these DFAA. Assuming an average C/N molar ratio of 3.5 for the DFAA (Fraga 2001), it seems that only $13 \%$ of the DOC deficit on the shelf can be assigned to DFAA consumption. The remaining $87 \%$ should be respired carbohydrates, based on the consideration that labile DOM is mainly composed of DFAA and carbohydrates (Kirchman et al. 1994, Rich et al. 1996). A decrease in $\mathrm{FDOM}_{\mathrm{M}}$ of $-1.5 \mathrm{ppb}$ eq QS is equivalent to the net photochemical degradation of $4.0 \mu \mathrm{M} \mathrm{C}$ of humic substances, which would be preferentially transformed into labile small organic molecules (Miller \& Moran 1997).

\section{CONCLUSIONS}

It has been demonstrated that DOM fluorescence can be used as a tracer for labile DOM (DFAA) production in the surface layer and for microbial decomposition processes in the bottom layer.

Fluorescence distributions suggested that humic acids and DFAA can be produced in either the surface or the bottom layer. FDOM ${ }_{\mathrm{T}}$ accumulated (1) in the BNL, after in situ production by intense microbial activity and/or after release from the porewaters of the pelagic sediment, and (2) in the photic layer, because of phytoplankton exudation or cell lysis. On the other hand, FDOM $\mathrm{M}_{\mathrm{M}}$ was produced in subsurface waters by in situ mineralisation, especially in the BNL and the sediments. The 2 study sites, a semi-enclosed bay and an open shelf, presented the same percentage of conversion of degradable organic carbon into humic substances as a by-product of microbial oxidation processes, $\sim 10 \%$.

Despite photodegradation of humic substances in the surface layer, accumulation of the humic material produced in San Simon Bay occurred in the mid-ría. On the contrary, photodegradation was the dominant process in the transit of surface waters of the ría to the shelf, where net consumption of humic substances was observed.
Although the literature on the photochemical degradation of humic substances is plentiful, there are no data about rates of microbial production of these macromolecules. In this work, we have found that humic substances can contribute up to $90 \%$ of the DOC excess in the BNL, an amount that demands future process-orientated studies.

Acknowledgements. The authors wish to thank the captain, crew and technicians of RV 'Mytilus' and the members of the groups of Oceanoloxía from the Instituto de Investigacións Mariñas and GOFUVI from the Universidade de Vigo for their inestimable help. Special thanks to S. Brea for assistance during the sample program, T. Rellán for $\mathrm{O}_{2}, \mathrm{POC}$ and $\mathrm{p}-\mathrm{CHO}$ analysis, C. G. Castro for nutrient analysis and J. L. Cortijo and S. Piedracoba for the meteorological data. T. Wyatt and 4 anonymous reviewers provided valuable criticisms on the manuscript. Financial support for this work came from CICYT grant numbers MAR1999-1039-C02-01 and REN2000-0880C02-01, and XUGA grant number PGIDT01MAR40201PN. A fellowship from the Spanish Ministerio de Ciencia y Tecnología funded M.N.-C. to carry out this work.

\section{LITERATURE CITED}

Aluwihare LI, Repeta DJ, Chen RF (1997) A major biopolymeric component to dissolve organic carbon in sea water. Nature 387:166-169

Álvarez-Salgado XA (1993) Transporte e balance biogeoquímico do nitróxeno na Ría de Arousa. PhD thesis, University of Santiago de Compostela

Álvarez-Salgado XA, Miller AEJ (1998) Simultaneous determination of dissolved organic carbon and total dissolved nitrogen in seawater by high temperature catalytic oxidation: conditions for precise shipboard measurements. Mar Chem 62:325-333

Álvarez-Salgado XA, Castro CG, Pérez FF, Fraga F (1997) Nutrient mineralization patterns in shelf waters of the western Iberian upwelling. Cont Shelf Res 17:1247-1270

Álvarez-Salgado XA, Doval MD, Pérez FF (1999) Dissolved organic matter in shelf waters off the Ría de Vigo (NW Iberian upwelling system). J Mar Syst 18:383-394

Álvarez-Salgado XA, Gago J, Míguez BM, Gilcoto M, Pérez FF (2000) Surface waters of the NW Iberian margin: upwelling on the shelf versus outwelling of upwelled waters from the Rías Baixas. Estuar Coast Shelf Sci 51:821-837

Álvarez-Salgado XA, Gago J, Míguez BM, Pérez FF (2001a) Net ecosystem production of dissolved organic carbon in a coastal upwelling system: the Ría de Vigo, Iberian margin of the North Atlantic. Limnol Oceanogr 46:135-147

Álvarez-Salgado XA, Doval MD, Borges AV, Joint I, Frankignoulle M, Woodward EMS, Figueiras FG (2001b) Off-shelf fluxes of labile materials by an upwelling filament in the NW Iberian Upwelling System. Prog Oceanogr 51: 321-337

Álvarez-Salgado XA, Figueiras FG, Pérez FF, Groom S and 10 others (2003) The Portugal coastal counter current off NW Spain: new insights on its biogeochemical variability. Prog Oceanogr 56:281-321

Amon RMW, Benner R (1996) Bacterial utilization of different size classes of dissolved organic matter. Limnol Oceanogr 41:41-51

Anderson LA (1995) On the hydrogen and oxygen content of marine phytoplankton. Deep-Sea Res I 42:1675-1680 
Benner R, Pakulski JD, McCarthy M, Hedges JI, Hatcher PG (1992) Bulk chemical characteristics of dissolved organic matter in the ocean. Science 255:1561-1564

Burdige DJ, Kline SW, Chen W (2004) Fluorescent dissolved organic matter in marine sediment pore waters. Mar Chem 89:289-311

Cabaniss SE, Shuman MS (1987) Synchronous fluorescence spectra of natural waters: tracing sources of dissolved organic matter. Mar Chem 21:37-50

Callahan J, Dai M, Chen RF, Li X, Lu Z, Huang W (2004) Distribution of dissolved organic matter in the Pearl River Estuary, China. Mar Chem 89:211-224

Carlson CA (2002) Production and removal processes. In: Hansell DA, Carlson CA (eds) Biogeochemistry of marine dissolved organic matter. Academic Press, San Diego, CA, p 91-151

Chavez FP, Toggweiler JR (1995) Physical estimates of global new production: the upwelling contribution. In: Summerhayes CP, Emeis KC, Angel MV, Smith RL, Zeitzschel B (eds) Upwelling in the ocean: modern processes and ancient records. John Wiley \& Sons, New York, p 13-32

Chen RF, Bada JL (1992) The fluorescence of dissolved organic matter in seawater. Mar Chem 37:191-221

Chen RF, Zhang Y, Vlahos P, Rudnick SM (2002) The fluorescence of dissolved organic matter in the Mid-Atlantic Bight. Deep-Sea Res II 49:4439-4459

Clark LL, Ingall ED, Benner R (1998) Marine phosphorus is selectively remineralized. Nature 393:426

Coble PG (1996) Characterization of marine and terrestrial DOM in seawater using excitation-emission matrix spectroscopy. Mar Chem 51:325-346

Coble PG, Green SA, Blough NV, Gagosian RB (1990) Characterization of dissolved organic matter in the Black Sea by fluorescence spectroscopy. Nature 348:432-435

Coble PG, Del Castillo CE, Avril B (1998) Distribution and optical properties of CDOM in the Arabian Sea during the 1995 Southwest Monsoon. Deep-Sea Res II 45:2195-2223

Del Vecchio R, Blough NV (2002) Photobleaching of chromophoric dissolved organic matter in natural waters: kinetics and modelling. Mar Chem 78:231-253

Del Vecchio R, Blough NV (2004) Spatial and seasonal distribution of chromophoric dissolved organic matter and dissolved organic carbon in the Middle Atlantic Bight. Mar Chem 89:169-187

Determann S, Reuter R, Willkomm R (1996) Fluorescent matter in the eastern Atlantic Ocean. Part 2. Vertical profiles and relation to water masses. Deep-Sea Res I 43:345-360

Determann S, Lobbes JM, Reuter R, Rullkötter J (1998) Ultraviolet fluorescence excitation and emission spectroscopy of marine algae and bacteria. Mar Chem 62:137-156

Doval MD, Álvarez-Salgado XA, Pérez FF (1997) Dissolved organic matter in a temperate embayment affected by coastal upwelling. Mar Ecol Prog Ser 157:21-37

Fraga F (2001) Phytoplanktonic biomass synthesis: application to deviations from Redfield stoichiometry. Sci Mar 65: 153-169

Gago J, Gilcoto M, Pérez FF, Ríos AF (2003) Short-term variability of $f \mathrm{CO}_{2}$ in seawater and air-sea $\mathrm{CO}_{2}$ fluxes in a coastal upwelling system (Ría de Vigo, NW Spain). Mar Chem 80:247-264

Gagosian RB, Ahmed SI, Farrington JW, Lee RF, Mantoura RFC, Nelson KH, Packard TT, Reinhart KL Jr (1978) Future research problems in marine organic chemistry. Mar Chem 6:375-382

Gilcoto M (2004) El campo termohalino como trazador de la dinámica de la Ría de Vigo y su acoplamiento meteorológico. PhD thesis, University of Vigo
Gilcoto M, Álvarez-Salgado XA, Pérez FF (2001) Computing optimum estuarine residual fluxes with (OERFIM) a multiparameter inverse method: application to the Ría de Vigo (NW Spain). J Geophys Res 106:31303-31318

Hansell DA (2002) DOC in the global ocean carbon cycle. In: Hansell DA, Carlson CA (eds) Biogeochemistry of marine dissolved organic matter. Academic Press, San Diego, CA, p 685-715

Hansell DA, Carlson CA (1998) Net community production of dissolved organic carbon. Global Biogeochem Cycles 12: $443-453$

Hayase K, Shinozuka N (1995) Vertical distribution of fluorescent organic matter along with AOU and nutrients in the equatorial Central Pacific. Mar Chem 48:283-290

Hayase K, Yamamoto M, Nakazawa I, Tsubota H (1987) Behaviour of natural fluorescence in Sagami Bay and Tokyo Bay, Japan - vertical and lateral distributions. Mar Chem 20:265-276

Hayase K, Tsubota H, Sunada I (1988) Vertical distribution of fluorescence organic matter in the North Pacific. Mar Chem 25:373-381

Haynes R, Barton ED (1990) A poleward flow along the Atlantic coast of the Iberian Peninsula. J Geophys Res 95: 11425-11441

Hedges JI (1992) Global biogeochemical cycles: progress and problems. Mar Chem 39:67-93

Hedges JI (2002) Why dissolved organics matter? In: Hansell DA, Carlson CA (eds) Biogeochemistry of marine dissolved organic matter. Academic Press, San Diego, CA, p 1-33

Hedges JI, Baldock JA, Gélinas Y, Lee C, Peterson ML, Wakeham SG (2002) The biochemical and elemental compositions of marine plankton: a NMR perspective. Mar Chem 78:47-63

Jaffé R, Boyer JN, Lu X, Maie N, Yang C, Scully NM, Mock S (2004) Source characterization of dissolved organic matter in a subtropical mangrove-dominated estuary by fluorescence analysis. Mar Chem 84:195-210

Kieber RJ, Hydro LH, Seaton PJ (1997) Photooxidation of triglycerides and fatty acids in seawater: implication toward the formation of marine humic substances. Limnol Oceanogr 42:1454-1462

Kirchman DL, Ducklow HW, McCarthy JJ, Garside C (1994) Biomass and nitrogen uptake by heterotrophic bacteria during the spring phytoplankton bloom in the North Atlantic Ocean. Deep-Sea Res I 41:879-895

Mayer LM, Schick LL, Loder III TC (1999) Dissolved protein fluorescence in two Maine estuaries. Mar Chem 64:171-179

McCarthy M, Pratum T, Hedges J, Benner R (1997) Chemical composite of dissolved organic nitrogen in the ocean. Nature 390:150-154

Miller WL, Moran MA (1997) Interaction of photochemical and microbial processes in the degradation of refractory dissolved organic matter from a coastal marine environment. Limnol Oceanogr 42:1317-1324

Mopper K, Schultz CA (1993) Fluorescence as a possible tool for studying the nature and the water column distribution of DOC components. Mar Chem 41:229-238

Nagata T (2000) Production mechanisms of dissolved organic matter. In: Kirchman DL (ed) Microbial ecology of the oceans. John Wiley \& Sons, New York, p 121-152

Niell FX (1977) Distribución y zonación de las algas bentónicas en la facies rocosa del sistema intermareal de las rías bajas gallegas. Invest Pesq (Spain) 41:219-237

Nieto-Cid M, Álvarez-Salgado XA, Brea S, Pérez FF (2004) Cycling of dissolved and particulate carbohydrates in a coastal upwelling system (NW Iberian Peninsula). Mar Ecol Prog Ser 283:39-54 
Obernosterer I, Herndl GJ (2000) Differences in the optical and biological reactivity of the humic and non humic dissolved organic carbon component in two contrasting coastal marine environments. Limnol Oceanogr 45: $1120-1129$

Ogawa H, Tanoue E (2003) Dissolved organic matter in oceanic waters. J Oceanogr 59:129-147

Prego R, Bao R, Vidal JR (1997) Upwelling influence on the Galician coast: silicate in shelf water and underlying surface sediments. Cont Shelf Res 17:307-318

Rich JH, Ducklow HW, Kirchman DL (1996) Concentrations and uptake of neutral monosaccharides along $140^{\circ} \mathrm{W}$ in the equatorial Pacific: contribution of glucose to heterotrophic bacterial activity and the DOM flux. Limnol Oceanogr 41:595-604

Ríos AF, Nombela MA, Pérez FF, Rosón G, Fraga F (1992) Calculation of runoff to an estuary, Ría de Vigo. Sci Mar 56:29-33

Rosón G, Álvarez-Salgado XA, Pérez FF (1997) A non stationary box model to determine residual fluxes in a partially mixed estuary, based on both thermohaline properties. Application to the Ría de Arousa (NW Spain). Estuar Coast Shelf Sci 44:249-262

Sharp JH, Beauregard AY, Burdige D, Cauwet G and 11 others (2004) A direct instrument comparison for measurement of total dissolved nitrogen in seawater. Mar Chem 84:181-193

Skoog A (1995) Organic carbon and humic substances in the marine environment. PhD thesis, University of Göteborg and Chalmers University of Technology

Skoog A, Wedborg M, Fogelqvist E (1996) Photobleaching of fluorescence and the organic carbon concentration in a coastal environment. Mar Chem 55:333-345

Sokal FF, Rohlf FJ (1995) Biometry. WH Freeman, New York

Souto C, Gilcoto M, Fariña-Busto L, Pérez FF (2003) Modelling the residual circulation of a coastal embayment affected by wind-driven upwelling: circulation

Editorial responsibility: Otto Kinne (Editor-in-Chief), Oldendorf/Luhe, Germany of the Ría de Vigo (NW Spain). J Geophys Res 108: $3340-3357$

Tenore KR, Bouer LF, Cal RM, García-Fernández C and 14 others (1982) Coastal upwelling in the Rías Bajas, NW Spain: contrasting the benthic regimes in the Rías of Arosa and Muros. J Mar Res 40:701-772

Thurman EM (1985) Organic geochemistry of natural waters. Chapter 10. Aquatic humic substances. Martinus Nijhoff/ Dr. W. Junk Publishers, Dordrecht, p 273-361

UNESCO (1985) The international system of units (SI) in oceanography. UNESCO Tech Pap Mar Sci 45. UNESCO, Paris

UNESCO (1986) Progress on oceanographic tables and standards 1983-1986: work and recommendations of the UNESCO/SCOR/ICES/IAPSO joint panel. UNESCO Tech Pap Mar Sci 50. UNESCO, Paris

Vähätalo AV, Wetzel RG (2004) Photochemical and microbial decomposition of chromophoric dissolved organic matter during long (months-years) exposures. Mar Chem 89: 313-326

Walsh JJ (1991) Importance of continental margins in the marine biochemical cycling of carbon and nitrogen. Nature 359:53-55

Wollast R (1998) Evaluation and comparison of the global carbon cycle in the coastal zone and in the open ocean. In: Brink KH, Robinson AR (eds) The sea, Vol 10. John Wiley \& Sons, New York, p 213-252

Wooster WS, Bakun A, McClain DR (1976) The seasonal upwelling cycle along the eastern boundary of the North Atlantic. J Mar Res 34:131-141

Yamashita Y, Tanoue E (2003) Chemical characterization of protein-like fluorophores in DOM in relation to aromatic amino acids. Mar Chem 82:255-271

Yentsch CS, Menzel DW (1963) A method for the determination of phytoplankton chlorophyll and phaeophytin by fluorescence. Deep-Sea Res Oceanogr Abstr 10:221-231

Submitted: July 17, 2004; Accepted: March 15, 2005

Proofs received from author(s): July 11, 2005 